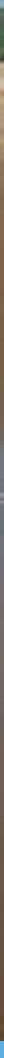

Costs of seabed protection on the Frisian Front and Central Oyster Grounds for the Dutch fishing sector

Addendum to LEI report 2015-145

Hans van Oostenbrugge, Mike Turenhout and Katell Hamon

LEI

WAGENINGEN UR 



\section{Costs of seabed protection on the Frisian Front and Central Oyster Grounds for the Dutch fishing sector}

Addendum to LEI report 2015-145

Hans van Oostenbrugge, Mike Turenhout and Katell Hamon

This study was carried out by LEI Wageningen UR and was commissioned and financed by the Dutch Ministry of Infrastructure and the Environment.

LEI Wageningen UR

Wageningen, June 2016

MEMORANDUM

LEI 2016-062

LE I 
Van Oostenbrugge, Hans, Mike Turenhout and Katell Hamon, 2016. Costs of seabed protection on the Frisian Front and Central Oyster Grounds for the Dutch fishing sector; Addendum to LEI report 2015-145. Wageningen, LEI Wageningen UR (University \& Research centre), LEI Memorandum 2016-062. 30 pp.; 12 fig.; 8 tab.; 8 ref.

Naast de kosten-batenanalyse die in Van Oostenbrugge et al. (2015) is uitgevoerd, biedt dit memorandum een schatting van de kosten van vier sluitingsvarianten voor het beschermen van het bentische ecosysteem van het Friese Front en de Centrale Oestergronden voor de Nederlandse visserij. De twee voorkeursvarianten leiden tot gelijkwaardige kosten voor de visserij, terwijl de kosten van de twee alternatieve combinaties hetzij $20 \%$ hoger hetzij $20 \%$ lager uitvallen.

This memorandum provides an estimation of the costs for four variant closures for the protection of the benthic ecosystem on the Frisian Front and the Central Oyster Grounds for the Dutch fishing sector in addition to the cost-benefit analysis carried out in Van Oostenbrugge et al. (2015). The two preferential variants lead to similar costs for the fisheries sector, whereas the costs of the two alternative combinations are either $20 \%$ higher or lower.

Key words: Fisheries, closures

This report can be downloaded for free at http://dx.doi.org/10.18174/383739 or at www.wageningenUR.nl/en/lei (under LEI publications).

(C) 2016 LEI Wageningen UR

P.O. Box 29703, 2502 LS The Hague, The Netherlands, T +31 (0)70 3358330 ,

E informatie.lei@wur.nl, www.wageningenUR.nl/en/lei. LEI is part of Wageningen UR (University \& Research centre).

\section{(cc) BY-NC}

For its reports, LEI utilises a Creative Commons Attributions 3.0 Netherlands license.

(C) LEI, part of DLO Foundation, 2016

The user may reproduce, distribute and share this work and make derivative works from it. Material by third parties which is used in the work and which are subject to intellectual property rights may not be used without prior permission from the relevant third party. The user must attribute the work by stating the name indicated by the author or licensor but may not do this in such a way as to create the impression that the author/licensor endorses the use of the work or the work of the user. The user may not use the work for commercial purposes.

LEI accepts no liability for any damage resulting from the use of the results of this study or the application of the advice contained in it.

LEI is ISO $9001: 2008$ certified.

LEI 2016-062 | Project code 2282200234

Cover photo: Shutterstock 


\section{Contents}

Summary $\quad 5$

S.1 Key findings $\quad 5$

$\begin{array}{ll}\text { S.2 Complementary findings } & 7\end{array}$

$\begin{array}{lll}\text { S.3 Method } & 7\end{array}$

$\begin{array}{ll}\text { Samenvatting } & 8\end{array}$

$\begin{array}{lll}\text { S.1 Belangrijkste uitkomsten } & 8\end{array}$

$\begin{array}{ll}\text { S.2 Overige uitkomsten } & 10\end{array}$

$\begin{array}{ll}\text { S.3 Methode } & 10\end{array}$

1

$\begin{array}{lr}\text { Introduction } & 11\end{array}$

2

$\begin{array}{ll}\text { Methods } & 14\end{array}$

$2.1 \quad$ Areas taken into consideration $\quad 14$

$\begin{array}{ll}2.2 & \text { Estimation of costs of closures } \\ \end{array}$

3

$\begin{array}{ll}\text { Results } & 16\end{array}$

3.1 Recent fishing activities $\quad 16$

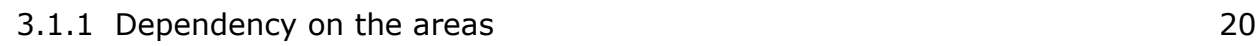

3.2 Value of the areas in Policy, Economy and Innovation scenarios 21

3.2.1 Displacement costs $\quad 23$

$\begin{array}{ll}3.2 .2 \text { Sensitivity analysis } & 26\end{array}$

4

$\begin{array}{ll}\text { Discussion and conclusions } & 27\end{array}$

$\begin{array}{lr}\text { References } & 29\end{array}$ 



\section{Summary}

\section{S.1 Key findings}

The two variants of closures for protection of the benthic communities of the Frisian Front and the Central Oyster Grounds proposed by the Ministry of Economic Affairs and the Ministry of Infrastructure and the Environment (COA_FFA and COB_FFB in Figure S.1) lead to similar costs for the fisheries sector. The costs of the two alternative combinations of the subareas are either around 20\% lower (COA_FFB) or 20\% higher (COB_FFA) (Table S.1). The current memorandum provides an overview of these costs in addition to the results of Van Oostenbrugge et al. (2015).
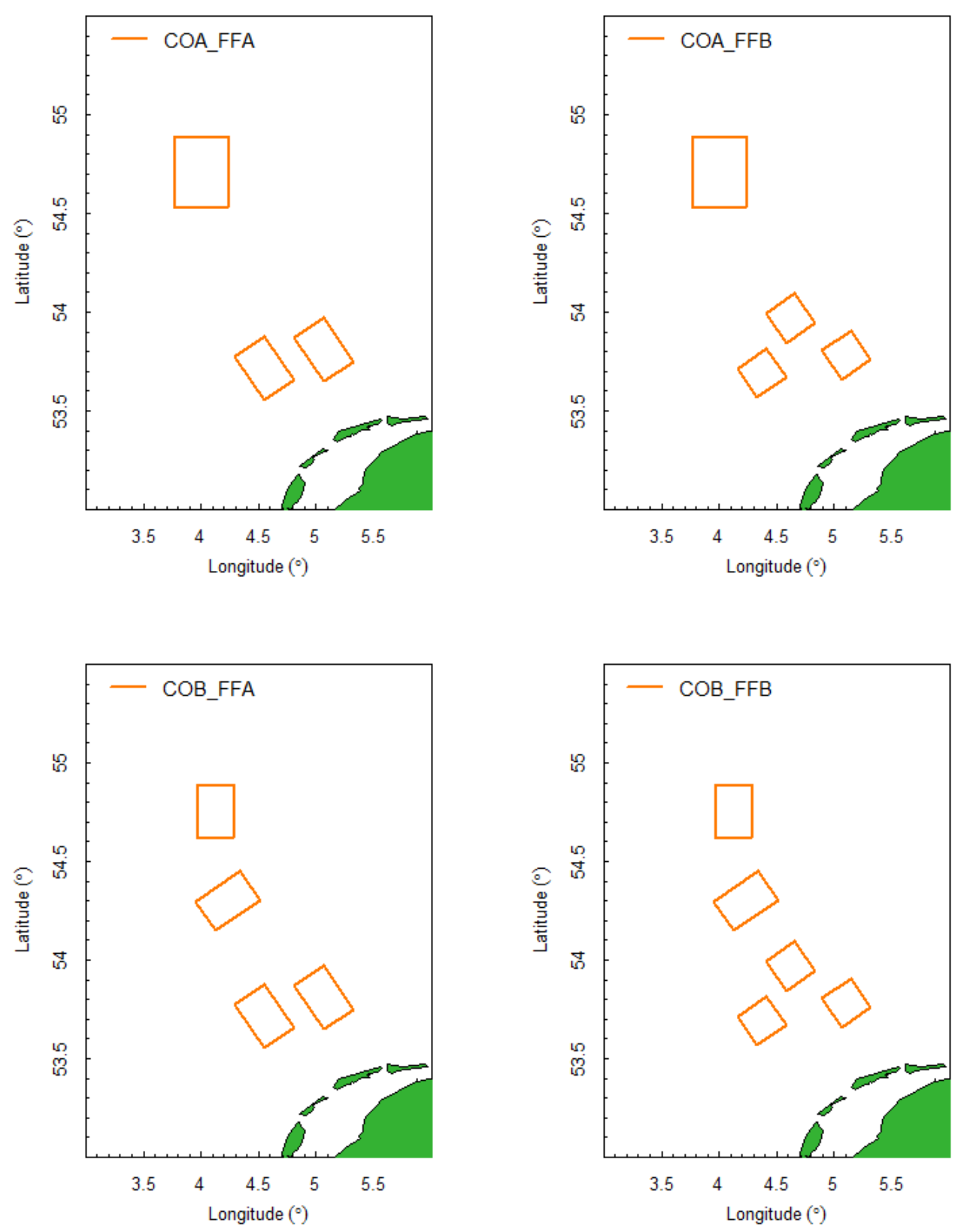

Figure S.1 Maps of the two preferential variants (COA_FFA and COB_FFB) and the alternative combinations of subareas (COA_FFB and COB_FFA) taken into consideration Source: Ministry of I\&M, processed by LEI. 
All four variants (Figure S.1) cover a total area of $2,400 \mathrm{~km}^{2}$, which is split equally in subareas in the Central Oyster Grounds and the Frisian Front. The variants vary in the size and location of the subareas, with three larger areas in preferential variant A and five smaller areas in preferential variant $B$. The two other variants taken into consideration are alternative combinations of the subareas of the preferential variants.

\section{Table S.1}

Overview of fishing activities in the variants (average 2008-20014) and the costs of variant closures in case of 4 Policy Innovation and Economics scenarios (PEI scenario 0-3) and 3 Displacement scenario (A-C). NPV, Net Present Value (future discounted costs over 30-year period); GVA, Gross Value Added

\begin{tabular}{|c|c|c|c|c|c|c|c|c|c|c|c|c|}
\hline Type of costs/benefits & & COA_FF & & & COA_FF: & & & COB_FFA & & & B_FFE & \\
\hline Days at sea & \multicolumn{3}{|c|}{275} & \multicolumn{3}{|c|}{219} & \multicolumn{3}{|c|}{313} & \multicolumn{3}{|c|}{257} \\
\hline Landings volume (tonnes) & \multicolumn{3}{|c|}{578} & \multicolumn{3}{|c|}{461} & \multicolumn{3}{|c|}{634} & \multicolumn{3}{|c|}{517} \\
\hline Landings value (m euro) & \multicolumn{3}{|c|}{1.5} & \multicolumn{3}{|c|}{1.2} & \multicolumn{3}{|c|}{1.7} & \multicolumn{3}{|c|}{1.4} \\
\hline GVA (m euro) & \multicolumn{3}{|c|}{0.5} & \multicolumn{3}{|c|}{0.4} & \multicolumn{3}{|c|}{0.6} & \multicolumn{3}{|c|}{0.5} \\
\hline Displacement scenario & $\mathbf{A}$ & B & C & A & B & C & A & B & C & $\mathbf{A}$ & B & C \\
\hline PEI scenario 0 & 2.2 & 5.4 & 0 & 1.7 & 4.3 & 0 & 2.5 & 6.2 & 0 & 2.1 & 5.2 & 0 \\
\hline PEI scenario 1 & 2.6 & 7.7 & 0 & 2.2 & 6.5 & 0 & 3.0 & 8.9 & 0 & 2.6 & 7.9 & 0 \\
\hline PEI scenario 2 & 2.1 & 4.9 & 0 & 1.7 & 3.8 & 0 & 2.4 & 5.7 & 0 & 2.0 & 4.7 & 0 \\
\hline
\end{tabular}

Depending on the assumptions taken, the total costs for the Dutch fishing sector, measured as the negative effect on net present value of the gross value added, range from 0 to $8.9 \mathrm{~m}$ euro. From the compiled overview of costs (Table S.1) the variants can be characterised as follows.

\section{COA_FFA}

Preferential variant A comprises three larger areas, one in the Central Oyster Grounds and two in the Frisian front. Of all variants analysed, this variant shows an intermediate level of fishing activities and closure of the areas result in intermediate costs for the fisheries.

\section{COB_FFB}

Preferential variant B comprises five smaller areas, two in the Central Oyster Grounds and three in the Frisian front. Similar to preferential variant A, this variant shows an intermediate level of fishing activities and closure of the areas result in intermediate costs for the fisheries.

\section{COA_FFB}

The alternative combination of the subareas of preferential variant A on the Central Oyster Grounds and the subareas of preferential variant B on the Frisian Front shows the lowest fishing activities, approximately $20 \%$ less than in both preferential variants. The closure of these areas also results in equally lower costs for the Dutch fishing sector.

\section{COB_FFA}

The alternative combination of the subareas of preferential variant B on the Central Oyster Grounds and the subareas of preferential variant A on the Frisian Front shows the highest fishing activities, approximately $20 \%$ more than in both preferential variants. The closure of these areas also results in equally higher costs for the Dutch fishing sector.

This note provides additional information on the estimated costs of the closures for the Dutch fisheries. The results show that there are consistent differences in the costs resulting from the closures under various external and displacement assumptions, reconfirming the relative differences in the impacts of the variants. The results also show that the absolute values of the future costs are highly uncertain and dependent on both external developments (prices, fish populations, management 
etc.) and the behavioural changes of fishermen and their economic consequences. Displacement scenario $\mathrm{C}$ assumes that the fishermen will be able to reallocate their fishing activities without having any costs.

\section{S.2 Complementary findings}

When compared to the original variants as defined in Van Oostenbrugge et al. (2015), the effects on the fishing sector of the variants in this memorandum are intermediate. The economic effect of variant COA_FFB, the least influential variant, is comparable to the effect of variant Capelin. The effects of the other variants described here are intermediate between the effects of variant Capelin and variant Eel. The effects of the closures are relatively low, when taking into account that the total size of the closures is much larger $\left(2,400 \mathrm{~km}^{2}\right)$ than the surface area of variant Capelin $\left(1,600 \mathrm{~km}^{2}\right)$. The main reason for this is the fact that the extra $800 \mathrm{~km}^{2}$ is situated on the Central Oyster Grounds, which is fished much less intensively than the Frisian Front.

\section{S.3 Method}

This memorandum is a partial extension of the complete cost-benefit analysis carried out by Van Oostenbrugge et al. (2015) to estimate the costs for the Dutch fishing sector of four variants of closures of areas in the Frisian Front and the Central Oyster Grounds. These closures for demersal fishing activities are set up in order to protect the benthic habitats. The study was requested by the Ministry of Infrastructure and the Environment.

In Van Oostenbrugge et al. (2015) other costs (including social effects, monitoring costs and enforcement costs) and ecological benefits were assessed as well as the importance of foreign fleets in the area. The inclusion of these other effects would be beneficial for a proper evaluation of the effectiveness of the area closures in reaching their management objectives.

The costs for the Dutch fishing sector were estimated using the methodology developed by Van Oostenbrugge et al. (2015). The main steps taken are:

- An inventory of the fishing activities in the variants is based on an analysis of detailed vessel position data (VMS), official logbook data and economic data from the LEI panel.

- Estimation of the economic value of the areas were made using four Policy, Economy and Innovation scenarios (PEI scenarios) which combined expected developments on fish stocks, fish prices, fuel prices, technical developments, management measures and other area closures.

- Costs of closing the areas were assessed using three displacement scenarios. These were based on scientific publications (scenario A), expert knowledge from the fishing sector (scenario B) and the assumption that the sector would be able to reallocate their activities without any costs (scenario $\mathrm{C}$ ).

- The resulting costs were combined into one indicator for the economic costs: the Net Present Value of the gross value added over a 30-year period. 


\section{Samenvatting}

\section{S.1 Belangrijkste uitkomsten}

De twee varianten voor een verbod op visserij in delen van het Friese Front en Centrale Oestergronden ter bescherming van de bentische gemeenschappen, zoals voorgesteld door het Ministerie van Economische Zaken en het Ministerie van Infrastructuur en Milieu (COA_FFA en COB_FFB in Figuur S.1), leiden tot vergelijkbare kosten voor de visserij. De kosten van de twee alternatieve combinaties van de subgebieden zijn hetzij circa $20 \%$ lager (COA_FFB) hetzij 20\% hoger (COB_FFA) (Tabel S.1). Naast de resultaten van Van Oostenbrugge et al. (2015) biedt het huidige memorandum een overzicht van deze kosten.
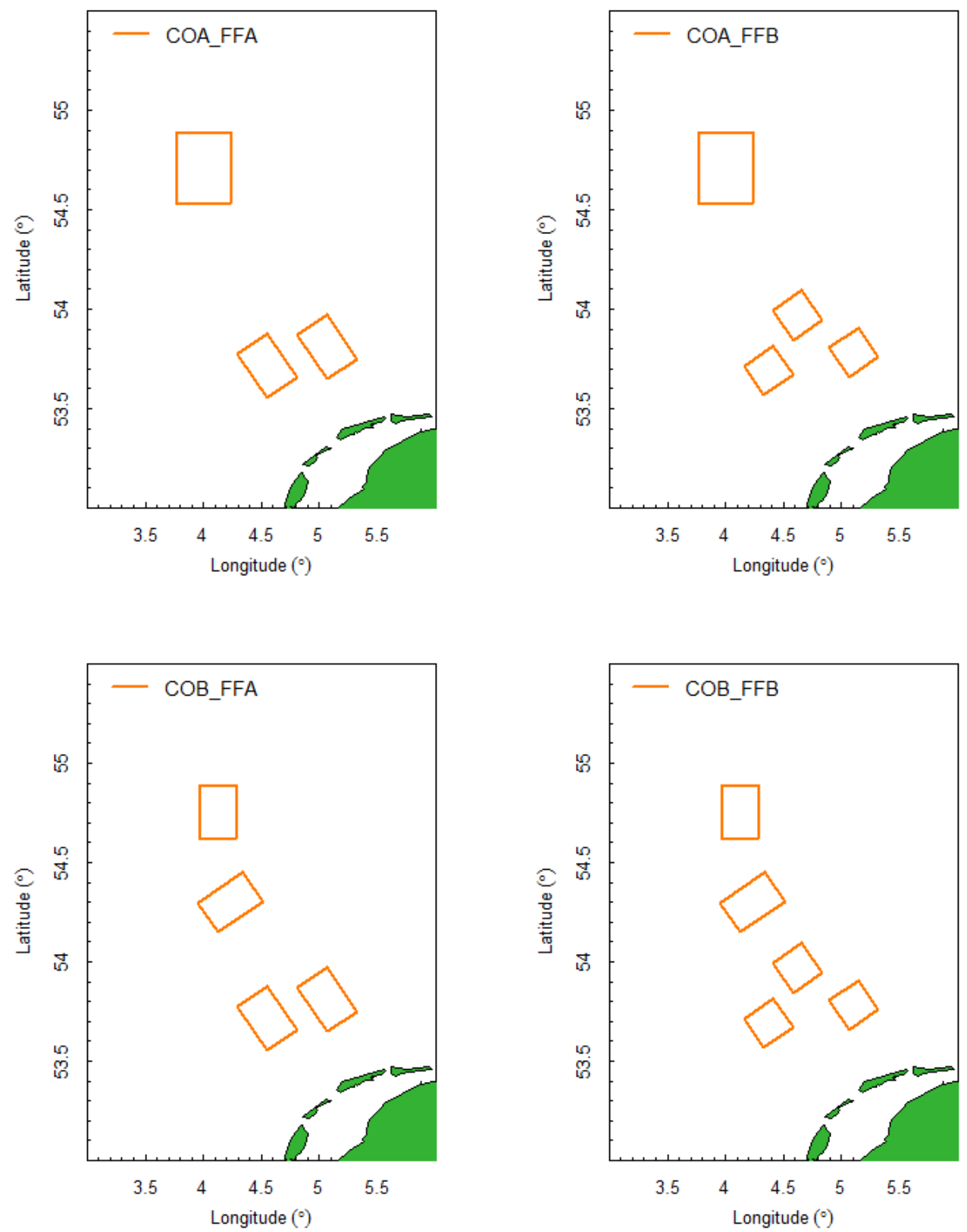

Figuur S.1 Kaarten van de twee voorkeursvarianten (COA_FFA en COB_FFB) en de alternatieve combinaties van subgebieden (COA_FFB en COB_FFA).

Bron: Ministerie van Infrastructuur en Milieu, bewerkt door het LEI. 
Alle vier de varianten (Figuur S.1) bestrijken een gebied ter grootte van totaal $2.400 \mathrm{~km}^{2}$ dat in gelijke delen is opgesplitst in subgebieden in de Centrale Oestergronden en het Friese Front. De varianten verschillen qua grootte en ruimtelijke ligging van de subgebieden, met drie grotere gebieden in voorkeursvariant A en vijf kleinere gebieden in voorkeursvariant B. De twee overige varianten zijn alternatieve combinaties van de subgebieden van de voorkeursvarianten.

\section{Tabel S.1}

Overzicht van visserijactiviteiten in de varianten (gemiddelde over 2008-20014) en de kosten van sluitingsvarianten in het geval van 4 beleids- en innovatiescenario's (PEI-scenario 0-3) en 3 verplaatsingsscenario ( $A-C$ ). NCW, netto contante waarde (toekomstige verdisconteerde kosten over een periode van 30 jaar); BTW, bruto toegevoegde waarde

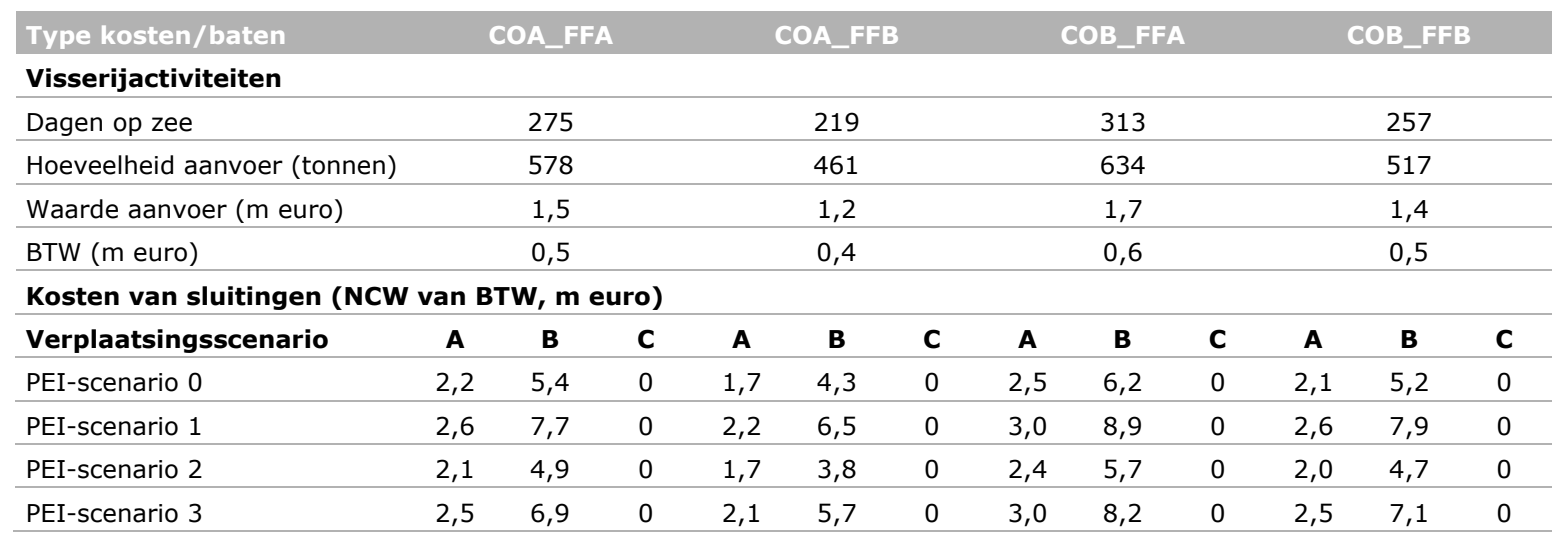

Afhankelijk van de ontleende veronderstellingen variëren de totale kosten voor de Nederlandse visserij, gemeten als het negatieve effect op de netto contante waarde van de bruto toegevoegde waarde, van 0 tot 8,9 m euro. Op basis van het samengestelde overzicht van kosten (Tabel S.1) zijn de varianten als volgt te karakteriseren.

\section{COA_FFA}

Voorkeursvariant A bestaat uit drie grotere gebieden, één in de Centrale Oestergronden en twee in het Friese Front. Van alle geanalyseerde varianten vertoont deze variant een gemiddeld niveau van visserijactiviteiten, waarbij sluiting van de gebieden resulteert in gemiddelde kosten voor de visserij.

\section{COB_FFB}

Voorkeursvariant B bestaat uit vijf kleinere gebieden, twee in de Centrale Oestergronden en drie in het Friese Front. Zoals bij voorkeursvariant A vertoont deze variant een gemiddeld niveau van visserijactiviteiten en sluiting van de gebieden resulteert in gemiddelde kosten voor de visserij.

\section{COA_FFB}

De alternatieve combinatie van de subgebieden van voorkeursvariant $A$ op de Centrale Oestergronden en de subgebieden van voorkeursvariant B op het Friese Front vertoont de laagste visserijactiviteiten; circa $20 \%$ minder dan in beide voorkeursvarianten. De sluiting van deze gebieden leidt dan ook tot lagere kosten voor de Nederlandse visserij.

\section{COB_FFA}

De alternatieve combinatie van de subgebieden van voorkeursvariant B op de Centrale Oestergronden en de subgebieden van voorkeursvariant A op het Friese Front vertoont de hoogste visserijactiviteiten; circa $20 \%$ meer dan in beide voorkeursvarianten. De sluiting van deze gebieden leidt dan ook tot hogere kosten voor de Nederlandse visserij.

Deze nota biedt extra informatie over de geschatte kosten van de sluitingen voor de Nederlandse visserij. De resultaten geven aan dat er bij diverse externe ontwikkelingen en verplaatsingsscenario's consistente verschillen bestaan in de kosten als gevolg van de sluitingen. Hiermee worden de relatieve 
verschillen in de effecten van de varianten bevestigd. De resultaten geven bovendien aan dat de absolute waarden van de toekomstige kosten zeer onzeker zijn en afhangen van zowel externe ontwikkelingen (prijzen, vispopulaties, beheer etc.) als van de gedragsveranderingen van vissers en de daaruit voortvloeiende economische gevolgen. Verplaatsingsscenario $C$ gaat ervan uit dat de vissers in staat zijn hun visserijactiviteiten zonder enige kosten te verplaatsen.

\section{S.2 Overige uitkomsten}

Vergeleken met de oorspronkelijke varianten in Van Oostenbrugge et al. (2015) hebben de varianten in dit memorandum een gemiddeld effect op de visserij. Het economische effect van variant COA_FFB, de minst ingrijpende variant, is vergelijkbaar met het effect van variant Capelin. De effecten van de overige varianten die hier zijn beschreven, houden het midden tussen de effecten van variant Capelin en variant Eel. De effecten van de sluitingen zijn relatief laag gezien het feit dat de totale omvang van de sluitingen veel groter is $\left(2.400 \mathrm{~km}^{2}\right)$ dan het oppervlaktegebied van variant Capelin $\left(1.600 \mathrm{~km}^{2}\right)$. De voornaamste reden hiervoor is dat de extra $800 \mathrm{~km}^{2}$ in de Centrale Oestergronden liggen, die veel minder intensief worden bevist dan het Friese Front.

\section{S.3 Methode}

Dit memorandum is een gedeeltelijke uitbreiding van de complete kosten-batenanalyse die door Van Oostenbrugge et al. (2015) is uitgevoerd ter inschatting van de kosten voor de Nederlandse visserij van vier varianten voor een verbod op visserij in delen van het Friese Front en Centrale Oestergronden. Deze sluitingen voor demersale visserijactiviteiten zijn opgesteld om de bentische habitats te beschermen. Het onderzoek is aangevraagd door het Ministerie van Infrastructuur en Milieu.

Door Van Oostenbrugge et al. (2015) werd tevens onderzoek verricht naar overige kosten (waaronder de kosten van sociale effecten, monitoring en handhaving) en de ecologische voordelen én naar het belang van de gebieden voor buitenlandse vloten. Deze overige effecten moeten ook worden meegewogen om de effectiviteit van de gebiedssluitingen bij het behalen van de beheerdoelen goed te kunnen evalueren.

De kosten voor de Nederlandse visserij zijn geschat met behulp van de methode die door Van Oostenbrugge et al. (2015) is ontwikkeld. Hierbij zijn de volgende belangrijkste stappen genomen:

- Een inventaris van de visserijactiviteiten in de varianten is gebaseerd op een analyse van gedetailleerde gegevens over de locatie van visserijschepen (VMS), officiële logboekgegevens en economische gegevens van het LEI-panel.

- $\mathrm{Er}$ is een schatting gemaakt van de economische waarde van de gebieden met behulp van vier beleids-, economische en innovatiescenario's (PEI-scenario's) met daarin een combinatie van verwachte ontwikkelingen van visbestanden, visprijzen, brandstofprijzen, technische ontwikkelingen, beheermaatregelen en overige gebiedssluitingen.

- De kosten van het sluiten van de gebieden werden geëvalueerd met behulp van drie verplaatsingsscenario's. Deze waren gebaseerd op wetenschappelijke publicaties (scenario A), vakkennis binnen de visserij (scenario $B$ ) en de veronderstelling dat de sector zijn activiteiten zonder enige kosten zou kunnen verplaatsen (scenario $\mathrm{C}$ ).

- De daaruit volgende kosten werden samengevoegd tot één indicator voor de economische kosten: de netto contante waarde van de bruto toegevoegde waarde over een periode van 30 jaar. 


\section{Introduction}

\section{Background}

The Frisian Front and Central Oyster Grounds have been selected for area protection measures under the Marine Strategy Framework Directive (MSFD, EU, 2008). Within this framework it is planned that part of - the Frisian Front and Central Oyster Grounds area will be closed for seabed disturbing fisheries, in order to protect the benthic community.

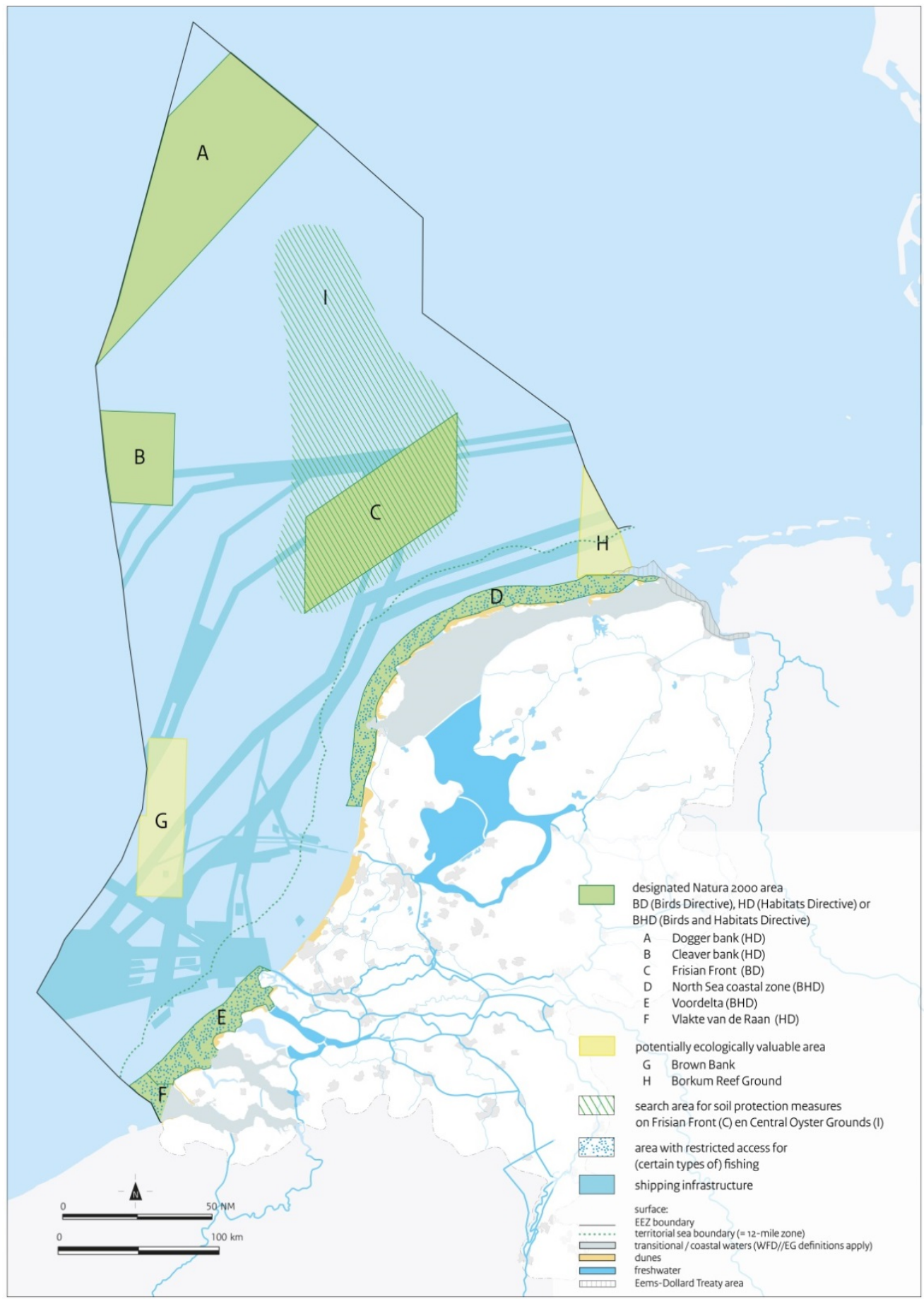

Figure 1.1 Area use in the Dutch part of the North sea, showing optional locations for fisheries restricting measures in the Central Oyster Grounds and the Frisian Front Source: adapted from Ministry of I\&M, Ministry of EZ (2014b). 
The Frisian Front and Central Oyster Grounds (Figure 1.1) have been selected for area protection measures under the MSFD because of high benthic biodiversity scores (Bos et al., 2011) relative to the rest of the Dutch North Sea. The deep silty benthic habitat and the front system present in the central North Sea (Frisian Front, Central Oyster Grounds) is characterised by a high species richness, high biomass, high density, the presence of vulnerable species and large-growing species. As these habitats are not listed in the Habitat Directive Annex I, they are excluded from Natura 2000 protection measures.

The overall aim of the Dutch government for the Dutch part of the North Sea is to protect $10-15 \%$ of the Dutch Continental Shelf against appreciably disrupting by human activities, with a minimum impact for the fishermen (Ministry of I\&M, Ministry of EZ, 2012). The fishery measures in Natura 2000 areas (North Sea Coastal Zone, Vlakte van de Raan, Voordelta, Dogger Bank and Cleaver Bank) partly contribute to this aim. The closures on the Frisian Front and Central Oyster Grounds should help to reach the $10-15 \%$ and contribute to the targets as defined in the Dutch Marine Strategy Part 1 (Ministry of I\&M, Ministry of EZ, 2012).

In preparation of a proposal for closures in the Frisian Front and the Central Oyster Grounds, various studies were carried out and a stakeholder process was conducted to develop options. First, an overview was made of available ecological and fishery knowledge for the Frisian Front and Central Oyster Grounds (Slijkerman et al., 2013). Next, studies to explore area closure measures using Marxan (Slijkerman et al., 2014) and an expert judgement workshop on the potential for recovery of the area after closure (Jongbloed et al., 2013) were conducted. In addition, recent trends and possible future developments in the Dutch fishing sector were described (Kuhlman and Van Oostenbrugge, 2014). These studies were used as input for a stakeholder consultation process that resulted in six variants for closures. The consequences of each of the variants were assessed in a cost-benefit analysis (Van Oostenbrugge et al., 2015). Based on the outcomes of the cost-benefit analysis and the input from stakeholders, the Ministry of I\&M formulated two preferential variants. Both variants consist of one or two areas in the Central Oyster Grounds and two or three areas in the Frisian Front (Figure 1.2).

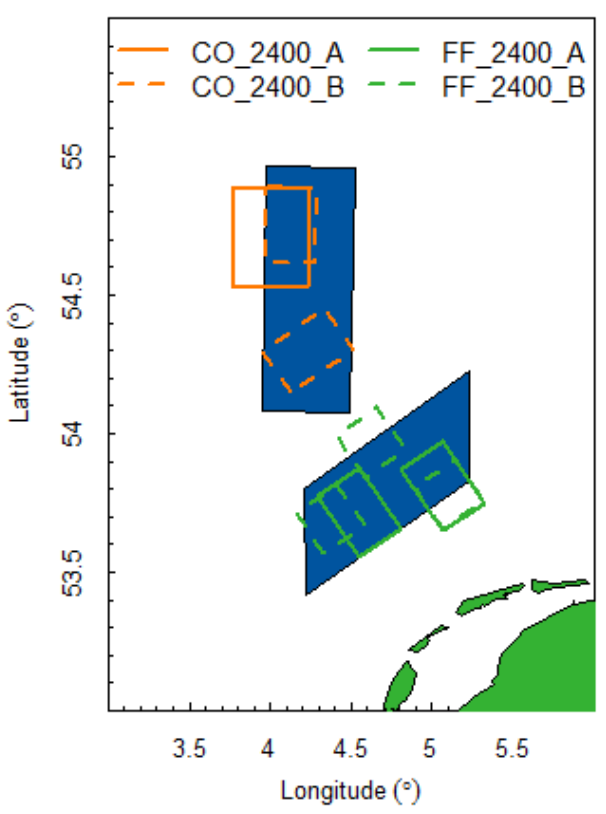

Figure 1.2 Area use in the Dutch part of the North sea, showing the subareas of the two preferential variants for fisheries-restricting measures in the Central Oyster Grounds and the Frisian Front

Source: Ministry of I\&M. 


\section{Objective addendum}

This addendum to the cost-benefit analysis provides an estimate of the costs for the Dutch fishing sector of the formulated two preferential variants and two alternative combinations of their subareas in the Frisian Front and the Central Oyster Grounds. This is done using the methodology as specified in the report on the cost-benefit analysis (Van Oostenbrugge et al., 2015). As such it is by no means a complete overview of the costs and benefits of the closures as in Van Oostenbrugge et al. (2015).

The project has been carried out by LEI Wageningen UR for the Ministry of I\&M in May 2016. 


\section{Methods}

\subsection{Areas taken into consideration}

The Ministry of I\&M and the Ministry of EZ have formulated two preferential variants consisting of areas on the Frisian Front and the Central Oyster Grounds. Both variants cover a total surface of $2,400 \mathrm{~km}^{2}, 1,200 \mathrm{~km}^{2}$ on the Frisian Front and 1,200 km² on the Central Oyster Grounds. Variant A consists of three (larger) areas; two located on the Frisian Front and one on the Central Oyster grounds. Variant B consists of five (smaller) areas; three located on the Frisian Front and two on the Central Oyster Grounds. In this study both preferential variants are taken into consideration as well as two alternative combinations of the areas. Figure 2.1 shows the various combinations of the closed areas that have been taken into consideration. The naming of the variants used in this memorandum combines information from the preferential variant name (either $A$ and $B$ ) and the location of the subareas ( $C O$ and FF), e.g. COA_FFB is the combination of the subarea of preferential variant $A$ on the Central Oyster Grounds and the subarea of preferential variant B on the Frisian Front.
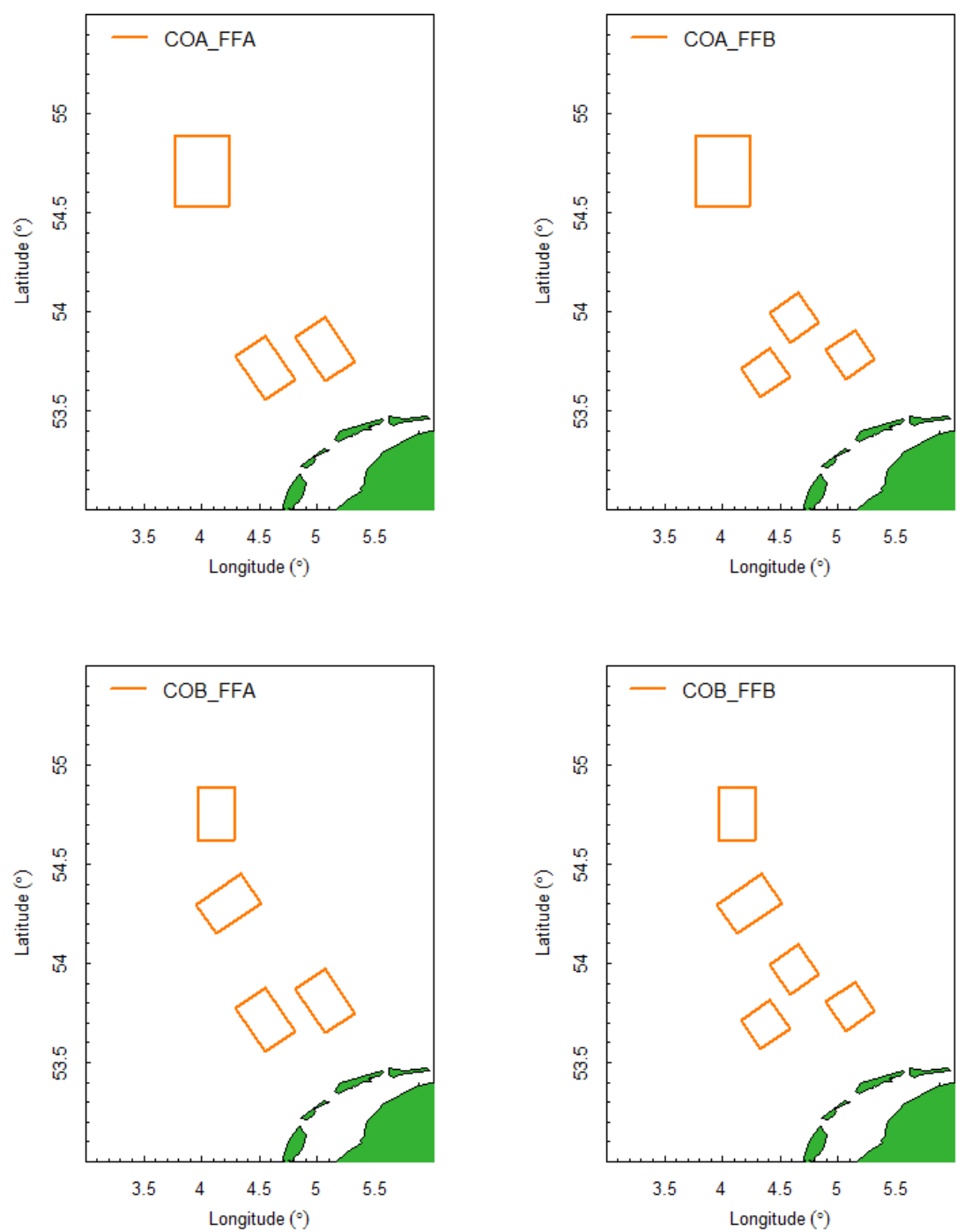

Figure 2.1 Maps of different variants taken into consideration. COA_FFA and COB_FFB are preferential variants $A$ and $B$ and COA_FFB and COB_FFA are the alternative combinations of the subareas on the Frisian Front and the Central Oyster Grounds Source: Ministry of I\&M, processed by LEI. 


\subsection{Estimation of costs of closures}

The costs of implementation of the closures for the Dutch fishing sector have been estimated using the same methodology as described in the cost-benefit analysis done previously and described extensively in Van Oostenbrugge et al. (2015). Here a summary of the methodology is provided with reference to the chapters of the original report.

The costs are estimated using the following steps:

Recent fishing activities (see Section 5.1)

An inventory of the fishing activities in the variants is based on an analysis of detailed vessel position data (VMS), official logbook data and economic data from the LEI panel.

Value of areas (see Section 6.1.1)

Estimation of the economic value of the areas were made using four Policy, Economy and Innovation scenarios (PEI scenarios). These PEI scenarios have been developed to assess potential effects of external developments on the fishing activities in the areas. The combined expected developments on fish stocks, fish prices, fuel prices, technical developments, management measures and other area closures.

Costs of displacement of fishing activities (see Section 6.1.2)

Costs of closing the areas were assessed using three displacement scenarios. Displacement scenario $A$ was based on scientific insights into the specific fishing opportunities in the areas, the effects of crowding and the effect of fishermen's knowledge. Displacement scenario B was based on the view of fishermen's representatives and also includes costs for some vessels that will stop fishing.

Displacement scenario $C$ assumed that the costs of the closures are negligible because fishermen will quickly adapt and find new fishing opportunities.

Combining future costs in Net Present Value (see Section 6.1.3)

The resulting costs were combined into one indicator for the economic costs: the Net Present Value of the GVA over a 30-year period. 


\section{$3 \quad$ Results}

In the results section, first the historic patterns in fishing activities in the area are described after which effects of the PEI scenarios on the fishing intensity in the areas and the resulting value are presented. Finally, the effects of the displacement scenarios are presented in combination with the PEI scenarios.

\subsection{Recent fishing activities}

In the period 2008-2014 the amount of fishing activities from the Dutch fishing sector varied in the various variants and from year to year (Table 3.1). The fishing activities and economic importance of both preferential variants were intermediate with the economic importance of variant B (COB_FFB) being somewhat higher than in variant A (COA_FFA); from 2008 to 2014, the Dutch sector spent around 255 to 275 days in the areas and the total contribution to the GVA was around $0.5 \mathrm{~m}$ euro per year. The differences in outcomes are mainly caused by the location choice for the Frisian Front subareas. The combinations with subarea FFA result in a higher landings value (300k euro per year) and contribution to the GVA (100k euro per year). The difference between the landings value and contribution to the GVA is smaller for the subareas in the Central Oyster Grounds (respectively $190 \mathrm{k}$ euro and 66k euro per year). Because of these differences, combination COB_FFA shows the highest level of fishing activities and economic importance; on average the Dutch fleet spent around 310 days in these areas creating a total Gross Added Value (GVA) of around $0.6 \mathrm{~m}$ euros. The amount of fishing activities in variant COA_FFB was the lowest and fishing activities and economic importance were around $40 \%$ less than for variant COB_FFA and $20 \%$ less than those of the preferential variants. The average total value of the landings by the Dutch demersal fishing sector amounted to approximately $250 \mathrm{~m}$ euros per year in the same period (www. visserijincijfers.nl).

Table 3.1

Overview of effort, landings and values and gross value added of the Dutch fishing sector in the areas of the different variants

\begin{tabular}{|c|c|c|c|c|c|c|c|c|}
\hline Variant & 2008 & 2009 & 2010 & 2011 & 2012 & 2013 & 2014 a) & Average \\
\hline \multicolumn{9}{|c|}{ Effort (days at sea) } \\
\hline COA_FFA & 336 & 356 & 303 & 219 & 305 & 227 & 182 & 275 \\
\hline COB_FFA & 394 & 382 & 326 & 277 & 324 & 252 & 237 & 313 \\
\hline COB_FFB & 337 & 332 & 290 & 214 & 205 & 193 & 224 & 257 \\
\hline COA_FFA & 495 & 497 & 549 & 316 & 1,260 & 500 & 428 & 578 \\
\hline COA_FFB & 432 & 436 & 500 & 339 & 692 & 451 & 381 & 461 \\
\hline COB_FFA & 572 & 525 & 575 & 475 & 1,263 & 534 & 493 & 634 \\
\hline COB_FFB & 508 & 464 & 526 & 497 & 695 & 485 & 446 & 517 \\
\hline \multicolumn{9}{|c|}{ Value ( 1,000 euros) } \\
\hline COB_FFB & 1,887 & 1,568 & 1,524 & 1,228 & 1,417 & 1,036 & 1,096 & 1,394 \\
\hline \multicolumn{9}{|c|}{ Gross Value Added (1,000 euros) } \\
\hline COA_FFA & 655 & 726 & 599 & 320 & 632 & 433 & 291 & 522 \\
\hline COA_FFB & 552 & 635 & 522 & 242 & 359 & 304 & 283 & 414 \\
\hline COB_FFA & 760 & 772 & 634 & 422 & 655 & 487 & 391 & 588 \\
\hline COB_FFB & 657 & 680 & 557 & 344 & 381 & 359 & 382 & 480 \\
\hline
\end{tabular}

a) preliminary estimates.

Source: Logbook data and VMS data, processed by LEI 


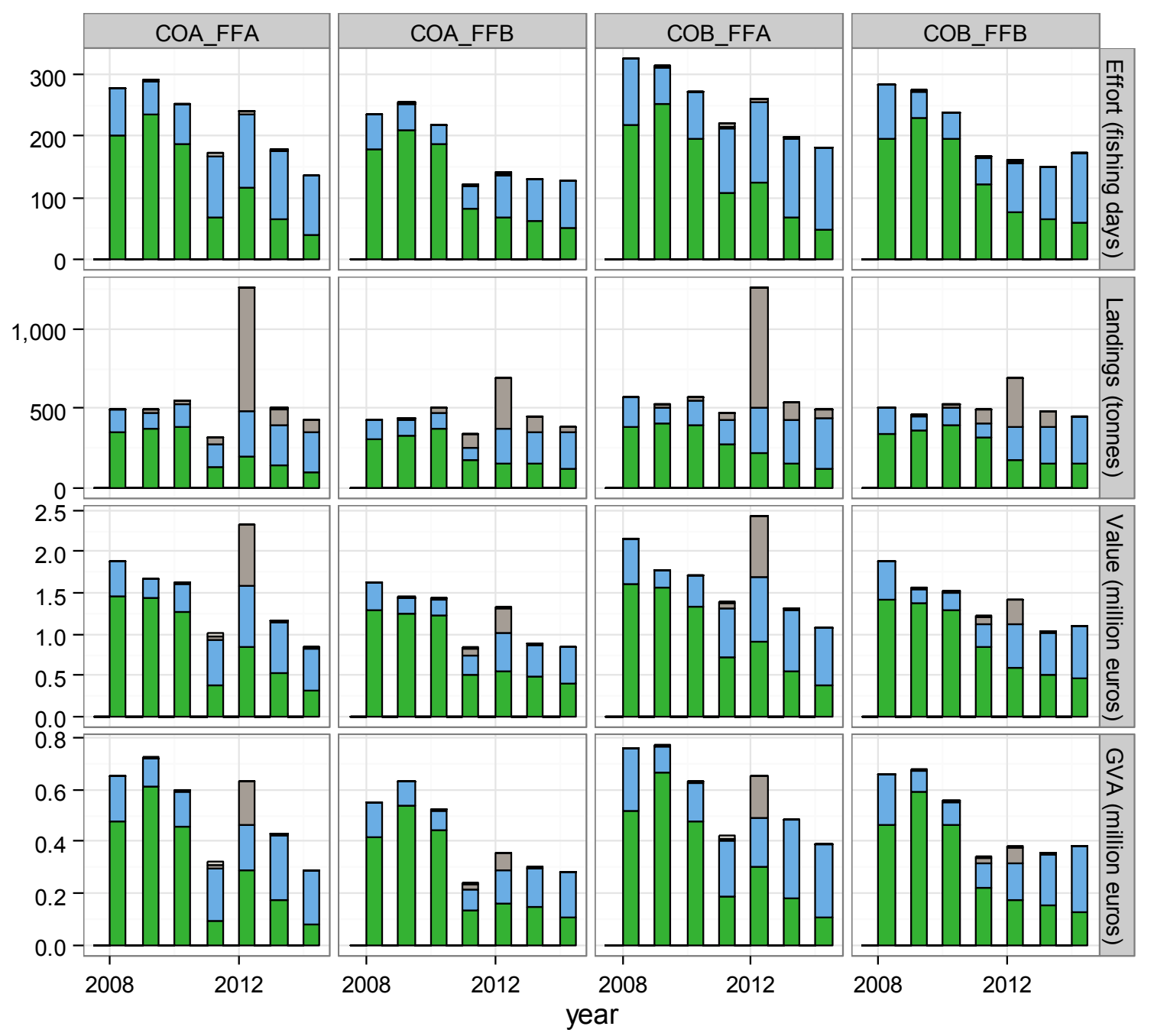

Gear $\square$ Beam trawlers $\square$ Demersal trawlers or seiners $\square$ Pelagic trawlers $\square$ Nets $\square$ Others

Figure 3.1 Historical trends of the fishing activities by the Dutch fleet in the areas of the variants. Effort, landings, value of landings and GVA are given by gear groups as specified in the European DCF Source: Logbook data and VMS data, processed by LEI.

For all variants the fishing activities have decreased during the seven years taken into consideration (Figure 3.1). On average, the effort, landings value and the GVA decrease by around 40 to $50 \%$. The reductions in landings volume are considerably less; $10-15 \%$ for all variants. This is mainly due to the general increase in fishing opportunity in the North Sea and decreasing prices. The reduction in fishing activities in the areas was lowest for preferential variant B (COB_FFB). For this variant GVA even increased slightly for the demersal gears in the period after an initial decrease until 2011. In contrast, preferential variant A shows the largest decrease in all fishing activity indicators.

The main gear types used in the area are bottom gears such as the traditional beam trawl and its innovative successors (pulse trawl, pulse wing and SumWing) and other types of bottom trawls. Over the period 2008-2014 the importance of the beam trawls (including pulse trawls) decreased considerably and the activity with this type of gear was partially replaced by other bottom trawls and seines such as otter trawl and twin trawl. Because of this, as from 2013 onwards beam trawls (including pulse trawls) were no longer the dominant group of gears used in the areas, but other bottom trawls and seines became more important (Figure 3.1). In 2012 considerable catches of pelagic fish have been caught in the areas, but these catches were incidental and they represent a low value because of the low prices of pelagic fish. Nets and other gears (dredges or shrimp trawls) are hardly used in the areas. 


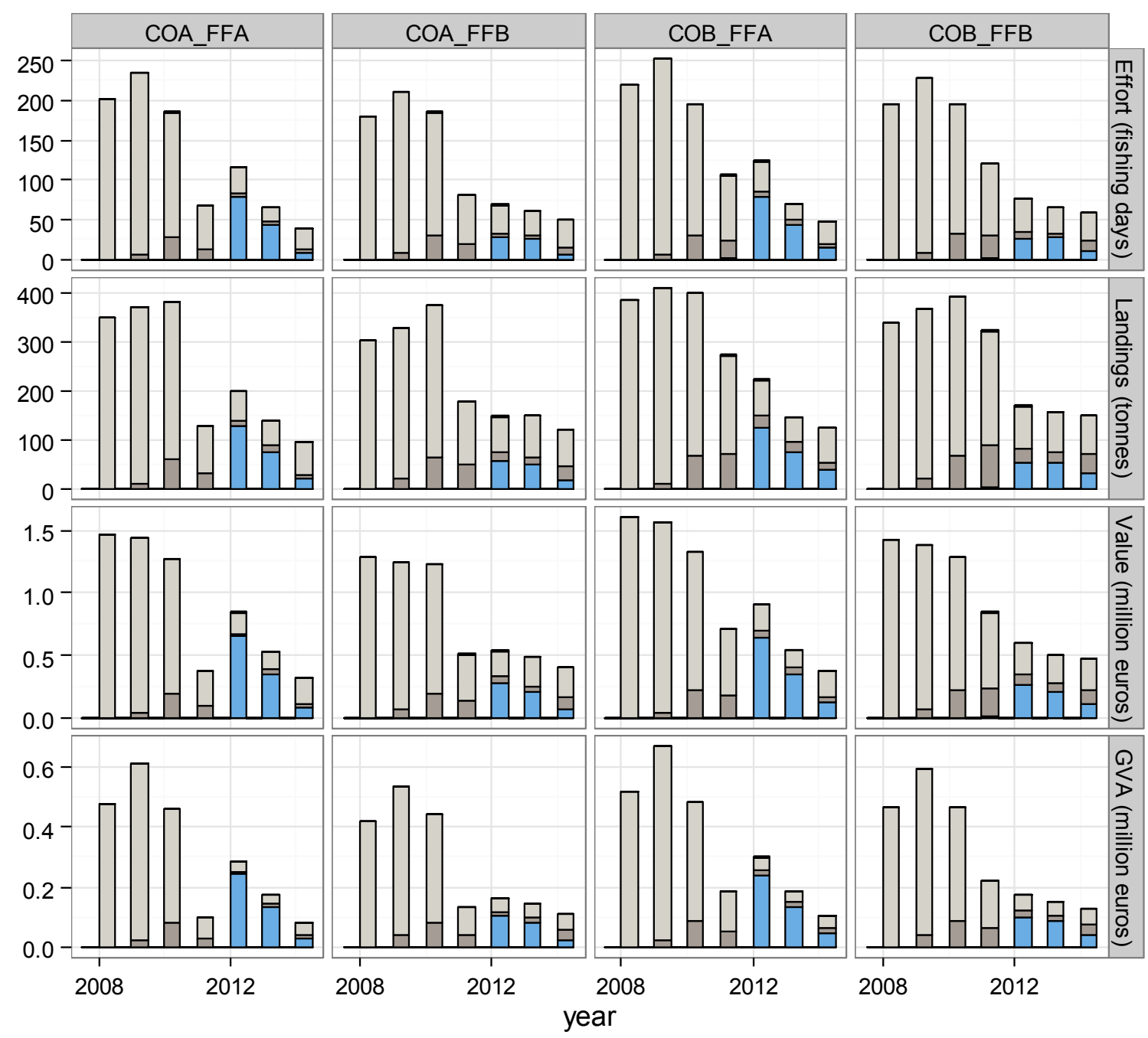

Gear Pulskor $\$ Pulswing $\triangle$ Sumwing $\square$ TBB $\square$ TBS

Figure 3.2 Historical trends of the fishing activities by the Dutch beam trawl fleet (including traditional and pulse trawl gears) in the areas of variants. Effort, landings, value of landings and GVA are given by gear type; TBB, traditional beam trawl; TBS, shrimp trawl

Source: Logbook data and VMS data, processed by LEI.

Activity levels of beam trawl fisheries (including pulse gears) in the variants are mainly influenced by the area choice in the Frisian Front (Figure 3.2) and in all areas the total fishing intensity of the beam trawl gears (including pulse gears) have been reduced considerably. In the latter years a considerable part of the fishing activities with the traditional beam trawl has been replaced by activities with innovative beam trawl gears such as the pulse wing. However, the use of pulse trawls in the area decreased from 2012 onwards and in 2014 the traditional beam trawl was used in approximately half of the fishing activities. Good fishing opportunities for plaice and relatively low fuel prices might have contributed to this development. 


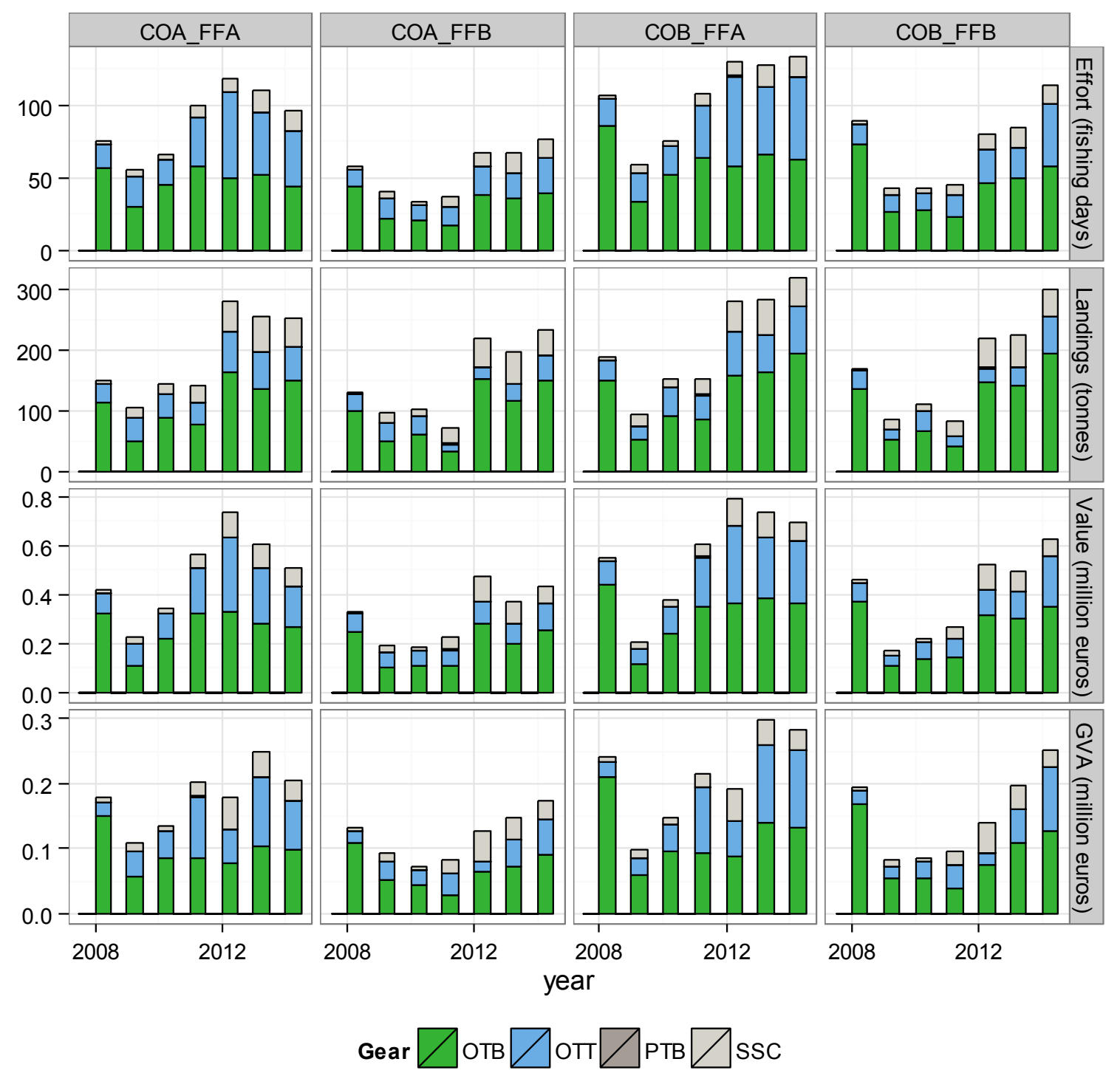

Figure 3.3 Historical trends of the fishing activities by the Dutch demersal trawlers in the areas of the different variants. Effort, landings, value of landings and GVA are given by gear type: OTB, otter trawl bottom; OTT, twin trawl; PTB, pair trawl bottom; SSC, Scottish seine (fly shoot fishery) (see also Appendix 6)

Source: Logbook data and VMS data, processed by LEI.

Activity levels of 'other trawls and seiners' vary among the variants, but all show the same general pattern. Activity levels have been relatively high during the last years and these gears have become the most important types used in the area (Figure 3.1).

Average fishing activity level is highest in variant COB_FFA (average around 100 fishing days and $0.2 \mathrm{~m}$ euro GVA) and lowest in variant COA_FFB (average around 50 fishing days and $0.1 \mathrm{~m}$ euro GVA) (Figure 3.3). The average level of the fishing activities of the preferential variants were similar, although the trends in the period after 2012 were slightly different. The most important gears used were bottom otter board trawl (OTB) and twin trawl (OTT). The importance of twin trawls (including the quadrig and multirig fishery) has increased and in recent years these gears are equally important as the bottom otter board trawl fishery. This has mainly been the result of changes in the relative availability of quota of the target species for these gears. The relative importance of the otter trawl fisheries was highest in most variants, whereas the flyshoot fishery has been of relatively minor importance. 


\subsubsection{Dependency on the areas}

The relative contribution of all variants to the total economy of the Dutch demersal fishing sector (the cutter fleet as specified in Taal et al., 2010) was less than $1 \%$ over the period 2008-2014, (Table 3.2). The contribution ranged from $0.5 \%$ (variant COA_FFB) to $0.7 \%$ (variant COB_FFA). The importance in value of landings and the GVA was highest om variant COB_FFA, which is mainly due to the areas being used for the fisheries of high valuable species like nephrops and sole. As for the total fishing activities, the dependency on the area has decreased over the last years.

\section{Table 3.2}

Relative contribution (\%) of the fishing activities in each of the variants to the fishing activities of the Dutch demersal fishing sector over the period 2008-2014

\begin{tabular}{|c|c|c|c|c|c|c|c|c|}
\hline & \multicolumn{2}{|c|}{ Effort (sea days) } & \multicolumn{2}{|c|}{ Landings (kg) } & \multicolumn{2}{|c|}{ Value (euros) } & \multicolumn{2}{|c|}{$\begin{array}{c}\text { Gross Value Added } \\
\text { (euros) }\end{array}$} \\
\hline & average & stdev & average & stdev & average & stdev & average & stdev \\
\hline COA_FFA & 0.58 & 0.12 & 0.53 & 0.14 & 0.63 & 0.23 & 0.63 & 0.20 \\
\hline COA_FFB & 0.46 & 0.12 & 0.47 & 0.11 & 0.50 & 0.15 & 0.50 & 0.18 \\
\hline COB_FFA & 0.66 & 0.12 & 0.61 & 0.12 & 0.71 & 0.21 & 0.71 & 0.18 \\
\hline COB_FFB & 0.54 & 0.12 & 0.55 & 0.10 & 0.58 & 0.15 & 0.58 & 0.18 \\
\hline
\end{tabular}

Source: Logbook data and VMS data, processed by LEI.

Although the overall contribution of the areas to the whole fishery is low, dependency can be high for individual vessels for specific seasons. Figure 3.4 shows the relative contribution of the fishing activities in the various variants to the total revenue of individual vessels per quarter and averaged over the period 2008-2014. This means that the vessels that are in the class between $10-20 \%$ dependency obtained between $10-20 \%$ of their total income of that quarter from the area over the period 2008-2014.

The dependency patterns are quite similar in all variants although dependency is somewhat higher in the variants COA_FFA and COB_FFA. The total number of vessels operating in the areas in a quarter ranges from around 25 to 40 . More than $80 \%$ of the vessels that fish in the areas are less than $10 \%$ dependent on these areas for their total revenue of that quarter and a limited number of vessels are more dependent. In quarter 1 , around 6 vessels get more than $10 \%$ of their revenues from the area in every variant. In variant COA_FFA and COB_FFA the number of vessels that have a dependency of more than $10 \%$ is also between 4 and 7 in quarter 2 and 3 . In variant COA_FFB and COB_FFB the number of vessels that obtain more than $10 \%$ of their revenues from the areas is around 2 to 3 . 


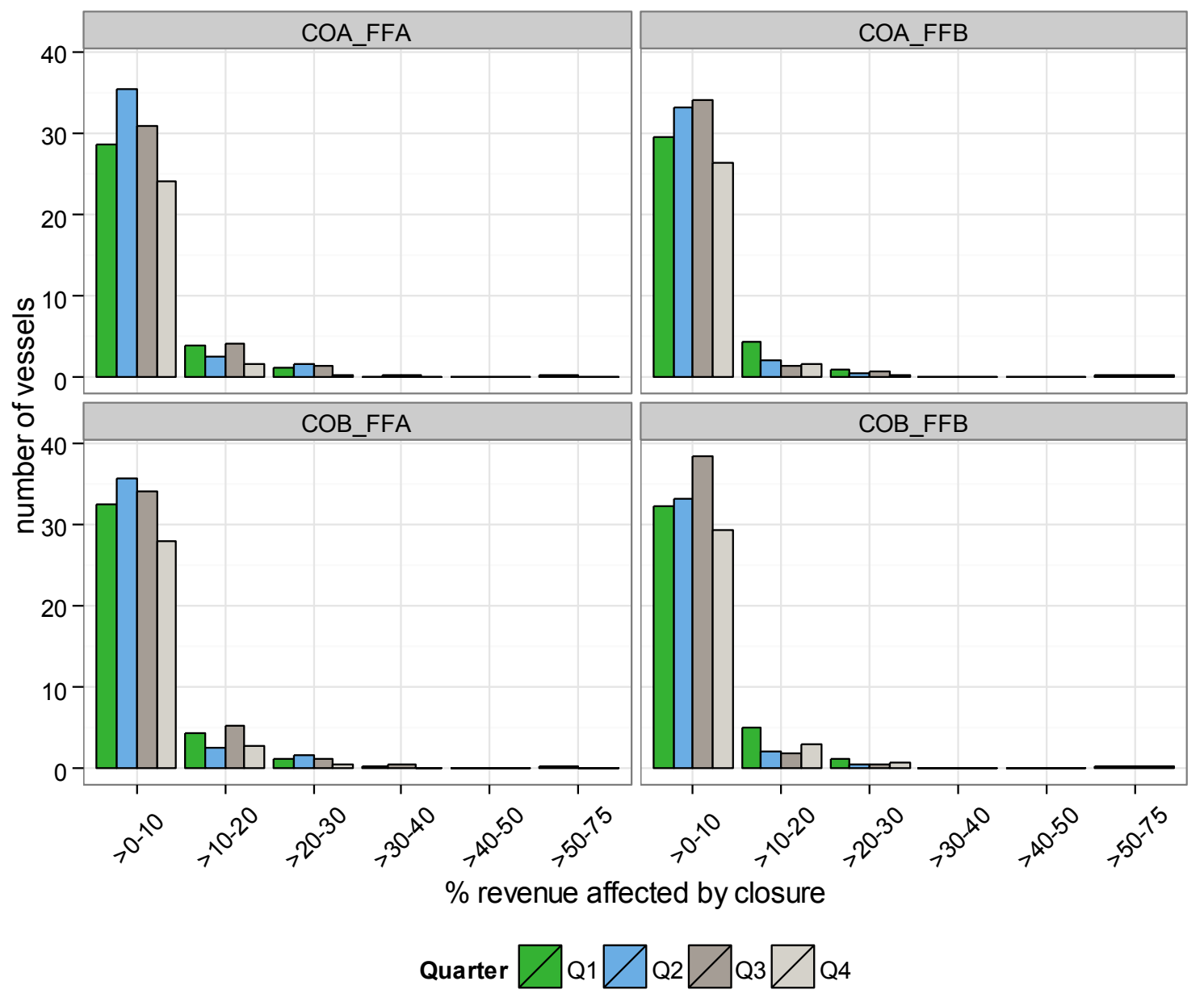

Figure 3.4 Quarterly stress profiles of the Dutch fishing fleet for the various variants, based on average dependency of the areas in the period 2008-2014. Dependency is measured by the percentage of the revenue that is taken from the areas Source: Logbook data and VMS data, processed by LEI.

\subsection{Value of the areas in Policy, Economy and Innovation scenarios}

The outcomes of the PEI scenarios illustrate the uncertain future for the Dutch fishing fleet. Depending on the developments taken into account the fishing activities in the areas and their resulting economic performance can vary significantly and the effects of other developments can be much larger than the effect of the choice of the area. However, the relative changes in the importance of the areas for the Dutch fishery are quite robust for changes in external developments as the patterns in the scenarios are quite similar. This is because the fishing activities in the areas of the variants are quite similar. 


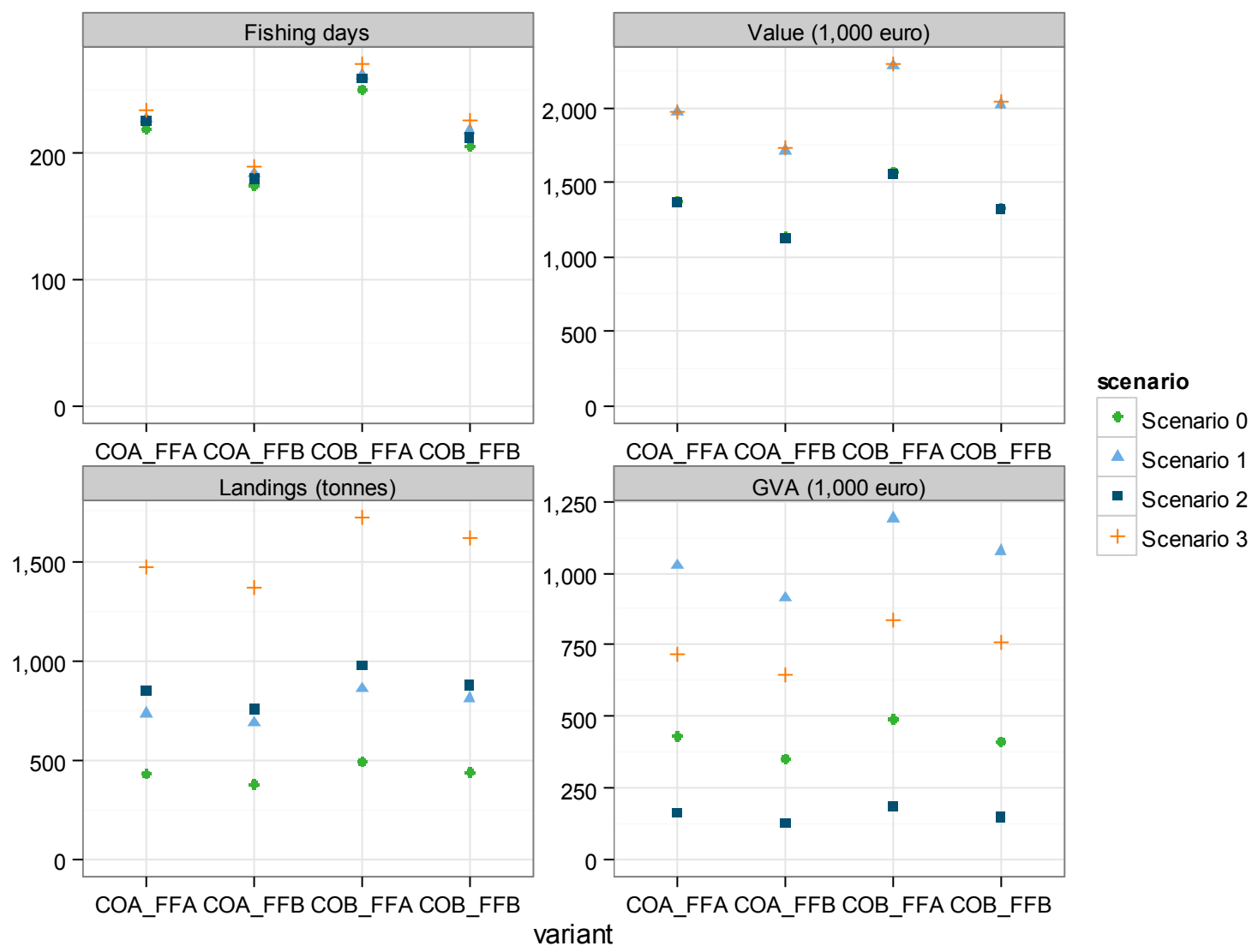

Figure 3.5 Consequences of the Policy, Economy and Innovation scenarios for the fishing activities of the Dutch fleet in the areas of various variants (annual totals) in case the areas are not closed Source: Logbook data and VMS data, processed by LEI.

All scenarios indicate that fishing activities in the areas would slightly increase in case the areas are not closed and that the value and volume of landings will be larger than in the current situation (scenario 0, Figure 3.5). This is realistic, based on the fact that the total fishing area will get smaller because of closures elsewhere and the fish stocks and thereby the possible landings will increase. Effort increases slightly due to area closures and the change to pulse gears that are not allowed north of 55 degrees latitude. This causes an effort increase of 7 to $10 \%$ in scenario 3, depending on the variant. The increase is highest for COB_FFB (10\%) and lowest for COA_FFA (7\%). For scenario 1 and 2 the increases are lower, but the ranking of the variants stays the same. The small difference between relative increases in effort for the variants indicate that the vessels active in the variants differ slightly in their spatial fishing patterns. Apparently, vessels that are fishing in variant COB_FFB are a little more active in other areas that have been identified as closures in the PEI scenarios than vessels that are active in variant COA_FFA.

Landings increase significantly in all PEI scenarios, ranging from $70 \%$ to $270 \%$. This leads to total landings that range from 1,400 tonnes for COA_FFB to 1,700 tonnes for COB_FFA in PEI scenario 3. The main reasons for this increase are the increase of fish biomass in PEI scenario 1 and the inclusion of discards that have to be landed in PEI scenario 2. Also the increase in effort contributes to the increased landings. The differences between the PEI scenarios are large, but despite the large changes, the ranking of the variants is stable and increases in landings are similar for all variants.

Landings value also increases in al PEI scenarios and variants, but the change is much smaller than for landings volume. This is mainly due to the low price of discards and the fact that the biomass of sole is assumed to be stable. Because of this the vast majority of extra fish that is caught has a relatively low value, especially in PEI scenario 2 . As for the landings volume, the effects are similar for all variants. 
GVA is influenced most by all the assumed changes in the PEI scenarios and shows that, depending on external developments, economic performance in the variants might vary considerably. In PEI scenario 1 the GVA increases by $130-160 \%$ of the original value and in PEI scenario 2 the GVA decreases by 62 to $64 \%$. In PEI scenario 3 these opposite effects partly mitigate each other, and the overall effects of all developments result in an increase of the GVA in all variants of 66 to $84 \%$. The relative order of the variants is stable in the various PEI scenarios; the GVA in variant COB_FFA is highest and that in variant COA_FFB lowest. In PEI scenario 3 the differences in GVA among the variants are somewhat less than in PEI scenario 0. This is due to the fact that the change in GVA is largest in case of variant COA_FFB and COB_FFB ( $82 \%$ and $84 \%$ respectively). The changes are however small.

\subsubsection{Displacement costs}

As a consequence of area closures a vessel can either increase its effort and costs or decrease its landings and income. Which option is chosen depends on the dependency of the vessels, the variant and the gear used. Because these characteristics vary among vessels, the two effects can occur simultaneously within the fleet; for some vessels income will be lower, while for others costs will increase. As vessels reallocate their fishing activities from the areas into other fishing areas, they will also affect other vessels. This effect of crowding has been taken into account separately in case of displacement scenario A.

Table 3.3 and Figures 3.6-3.7 show the effects of displacement of the fishing activities from the closed areas for the vessels directly affected by the closures. As displacement scenario $C$ results in 0 costs for the fisheries, these have not been presented in the graphs, but have been mentioned in the graph and table headers.

\section{Table 3.3}

Net effects of effort displacement in case of area closures for the Dutch fleet in the first, second and fifth year after the closure for PEI scenario $O$ and displacement scenario $A$ and B. Only the costs for directly affected vessels are shown. For displacement scenario $C$ the changes in effort, landings, value and Gross Value Added are 0

\begin{tabular}{|c|c|c|c|c|c|c|c|c|}
\hline \multirow[b]{2}{*}{ Displacement scenario } & \multicolumn{2}{|c|}{ Effort (sea days) } & \multicolumn{2}{|c|}{ Landings (tonnes) } & \multicolumn{2}{|c|}{ Value (1,000 euros) } & \multicolumn{2}{|c|}{$\begin{array}{l}\text { Gross Value Added } \\
\text { (1,000 euros) }\end{array}$} \\
\hline & A & B & A & B & A & B & A & B \\
\hline Year 1 & 0.9 & 0.0 & -28.0 & -134.2 & -89.4 & -438.6 & -87.9 & -407.1 \\
\hline Year 2 & 0.9 & 0.0 & -22.5 & -120.5 & -70.6 & -391.4 & -70.4 & -363.3 \\
\hline \multicolumn{9}{|l|}{ COA_FFB } \\
\hline Year 1 & 0.4 & 0.0 & -22.8 & -110.3 & -67.5 & -332.6 & -64.8 & -308.4 \\
\hline Year 2 & 0.4 & 0.0 & -19.6 & -102.4 & -57.6 & -307.8 & -55.6 & -285.5 \\
\hline Year 5 & 0.4 & 0.0 & -18.0 & -99.2 & -52.6 & -297.9 & -51.0 & -276.3 \\
\hline Year 5 & 1.0 & 0.0 & -22.7 & -131.4 & -70.5 & -424.6 & -70.5 & -394.2 \\
\hline \multicolumn{9}{|l|}{ COB_FFB } \\
\hline Year 1 & 0.5 & 0.0 & -30.4 & -141.2 & -91.6 & -430.2 & -87.4 & -399.0 \\
\hline Year 2 & 0.5 & 0.0 & -24.1 & -125.5 & -71.9 & -380.8 & -69.1 & -353.2 \\
\hline Year 5 & 0.5 & 0.0 & -21.0 & -119.2 & -62.0 & -361.1 & -59.9 & -335.0 \\
\hline
\end{tabular}

Source: Logbook data and VMS data, processed by LEI

Table 3.3 and Figure 3.6 and 3.7 show that the overall pattern in the effects of effort displacement for scenarios A and B is comparable in the PEI scenarios. The effects of closing the areas on the GVA of the vessels affected range from $60 \mathrm{k}$ euro to $460 \mathrm{k}$ euro in the first year after the closure in PEI 
scenario 0 (base case). The consequences of displacement are lowest for variant COA_FFB (65k euro and 309k euro for the GVA in year 1 in displacement scenario $A$ and $B$ respectively). Both preferential variants (COA_FFA and COB_FFB) show intermediate values (88k euro and around 400k euro for the GVA in year 1 in displacement scenario $A$ and $B$ respectively) and the values of variant COB_FFA are highest (100k euro and around 464k euro for the GVA in year 1 in displacement scenario $A$ and $B$ resp.).

For all variants, the effects of displacement in scenario $B$ are around 4 to 5 times higher than those in displacement scenario $A$. This accounts for the landings volume, landings value and the resulting GVA. Only in case of displacement scenario $A$, closures result in extra effort as it is assumed that fishermen will compensate losses in catch efficiency for sole by either making extra seadays or by transferring their fishing rights to other vessels that will use them. In scenario $B$ it is assumed that the fishing fleet is not able to extend its fishing activities to compensate for the loss of catch efficiency (see also Van Oostenbrugge et al., 2015). Table 3.3. shows however that the extra effort in displacement scenario $A$ is very small ( $<1$ seaday). In case of displacement scenario $C$ there is no difference in the resulting costs of the variants as for all variants, the costs are 0 .

In both displacement scenario A and B the effect of displacement is largest in the first year after the closure as the vessels that are dependent on the closed areas experience the greatest reduction in fishing efficiency. In all variants the results show a considerable decrease over the years (10-30\%), because a considerable proportion of the fishing activities is carried out by vessels that are categorised as dependent on the areas. In case of displacement scenario $C$ there is no reduction in the effects of displacement over time.

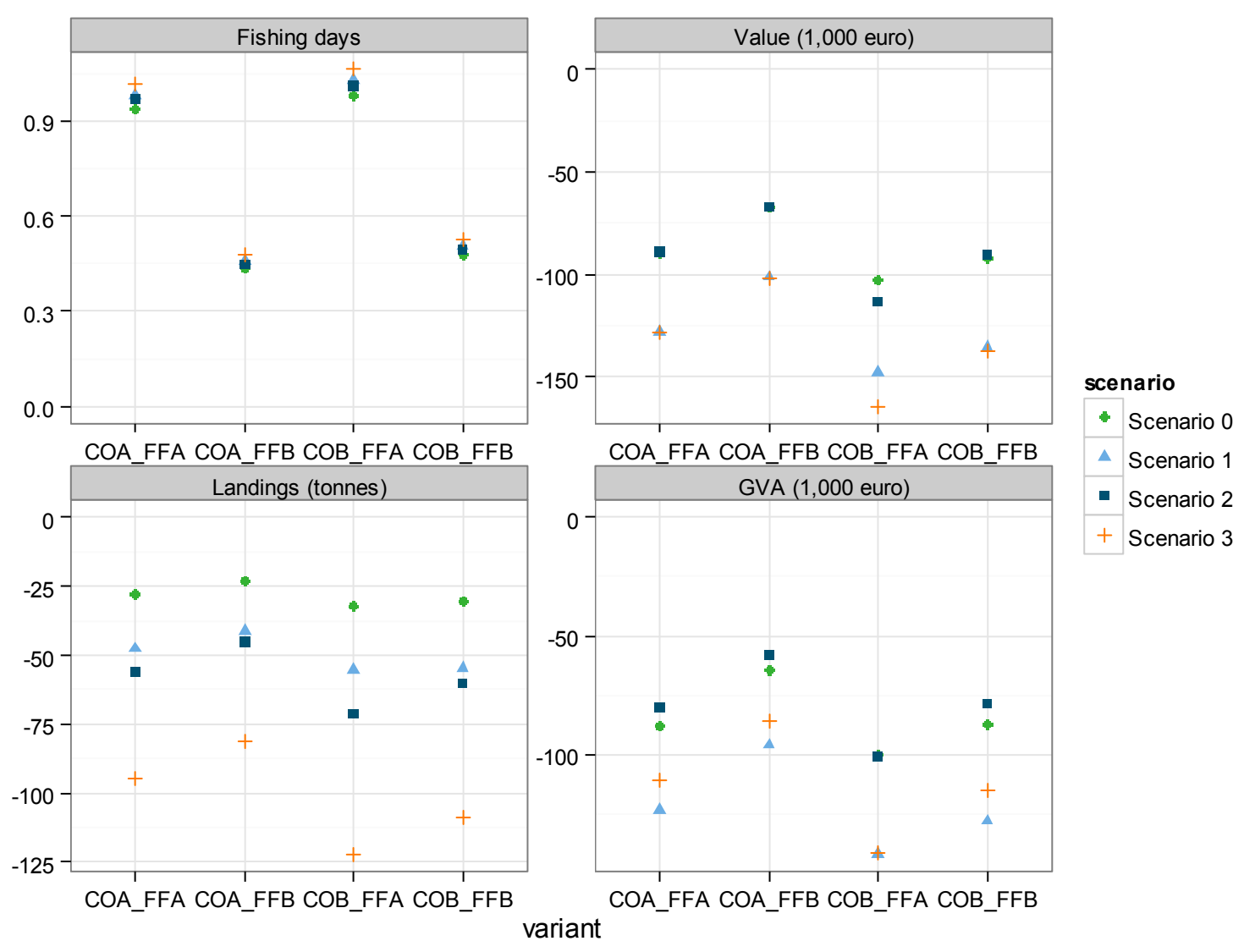

Figure 3.6 Effects of effort displacement on the effort, landings volume, landings value and GVA in the first year after the closure for displacement scenario A. Series show the effects of the PEI scenarios (see text for further explanation) Source: Logbook data and VMS data, processed by LEI. 


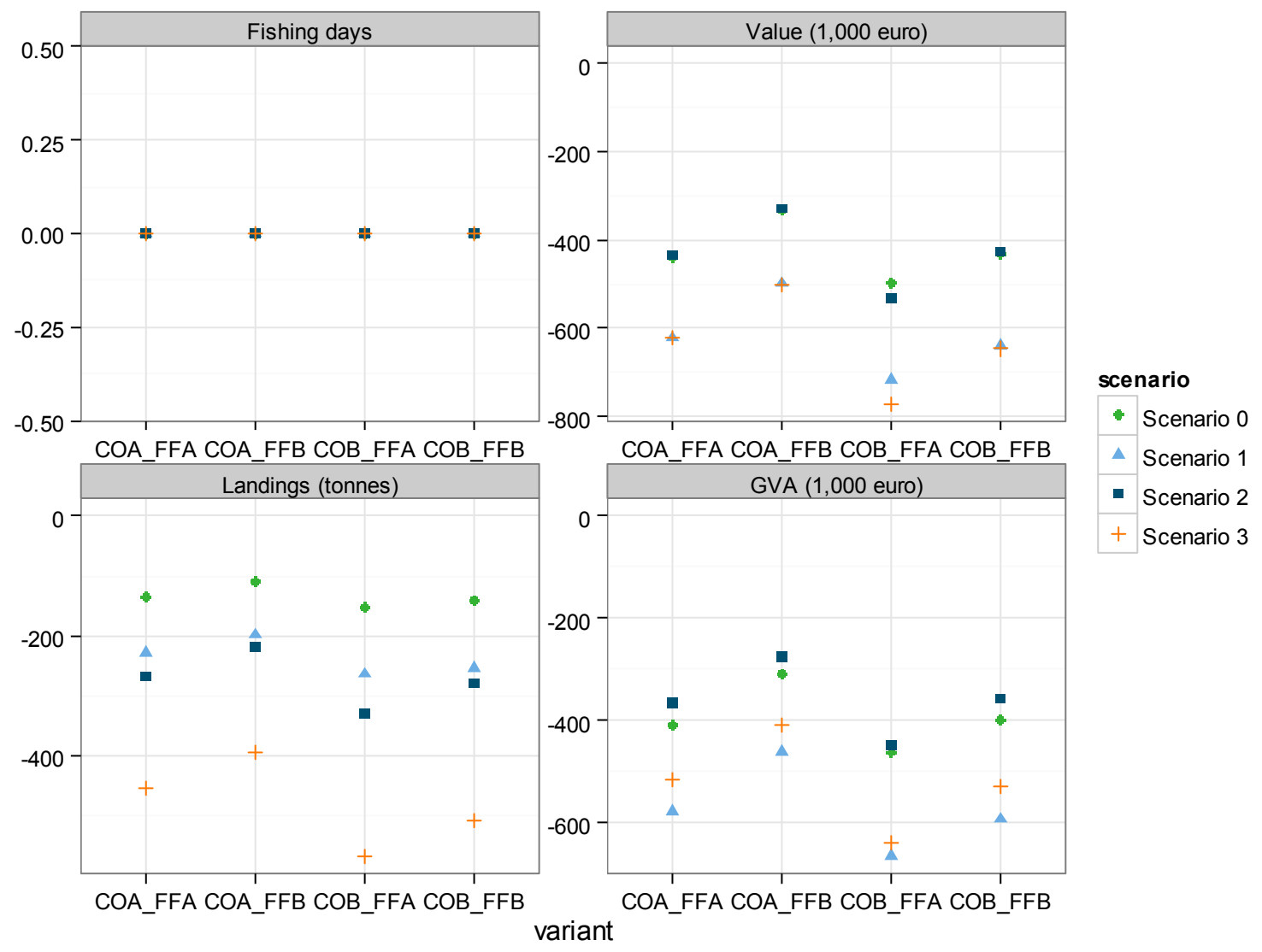

Figure 3.7 Effects of effort displacement on the effort, landings volume, landings value and GVA in the first year after the closure for displacement scenario B. Series show the effects of the PEI scenarios (see text for further explanation)

Source: Logbook data and VMS data, processed by LEI.

Figures 3.6 and 3.7 show the impacts in the first year after the closure in the various PEI scenarios. Comparison of Figures 3.6 and 3.7 shows that the patterns for the two displacement scenarios are nearly identical. Only the extent of the effect is much larger in case of displacement scenario B and in displacement scenario $B$ the number of fishing days does not change. The high decrease in landings volume in PEI scenario 3 can be explained by the overall increase in landings, both as a result of increased fish stock size and because of the implementation of the landing obligation (see also p. 20). The effect of the PEI scenarios on the impact of displacement is large, similar to the effects previously discussed on the value of the areas. Especially scenario 1 and 3 increase the effect of the closures considerably by around $40 \%$. The relative changes in the effects are however similar for all variants, so the ranking of the variants is not changed.

In case of displacement scenario $A$, additional costs are estimated for the whole fleet, based on the assumed crowding effect. This is the effect that the vessels that have reallocated their fishing activities have on the catch efficiency of the vessels that already utilise these areas; because it is getting more crowded in the remaining fishing grounds, the fishing efficiency will decrease. In displacement scenario $B$ this phenomena has not been addressed explicitly. Table 3.4 summarises the effects of crowding for the whole Dutch fleet, based on the effort increase in the remaining open area for each of the PEI scenarios. The effect of increased crowding ranges from $0.9 \mathrm{~m}$ euros in variant COA_FFB in PEI-scenario 0 to $1.4 \mathrm{~m}$ euros in variant COB_FFA and is almost proportional to the amount of effort displaced. The impact of the PEI scenarios is small. 
Table 3.4

Overview of the resulting effect of crowding for the various variants and PEI scenarios. See text for explanation. NPV; Net present value over 30 years

\begin{tabular}{|c|c|c|c|c|}
\hline & \multicolumn{4}{|c|}{ PEI scenarios } \\
\hline \multicolumn{5}{|c|}{ Effort displaced (\% of total effort of Dutch fleet) } \\
\hline COA_FFB & 0.46 & 0.48 & 0.47 & 0.50 \\
\hline COB_FFA & 0.66 & 0.68 & 0.68 & 0.71 \\
\hline \multicolumn{5}{|c|}{ Relative effect on Value per sea day of Dutch fleet (\%) } \\
\hline COA_FFA & 0.04 & 0.04 & 0.04 & 0.04 \\
\hline COA_FFB & 0.03 & 0.03 & 0.03 & 0.03 \\
\hline COB_FFA & 0.04 & 0.05 & 0.05 & 0.05 \\
\hline COA_FFB & 0.9 & 1.0 & 1.0 & 1.0 \\
\hline COB_FFA & 1.3 & 1.4 & 1.4 & 1.4 \\
\hline COB_FFB & 1.1 & 1.2 & 1.1 & 1.2 \\
\hline
\end{tabular}

Table 3.5 summarises the effects of both PEI scenarios and displacement scenarios on the net present value of the GVA. The Net Present Value indicates all future costs for the closures, discounting costs for a period of 30 years (See also Chapter 2). Changes in the NPV of GVA ranges from -0.m euros for displacement scenario $C$ to $-9 \mathrm{~m}$ euros for variant COB_FFA in PEI scenario 1 and displacement scenario B. The costs of variant COA_FFB are in general lowest and the costs of variant COB_FFA are highest approximately $40 \%$ higher than the costs of COA_FFB. The costs of both preferential variants (COA_FFA and COB_FFB) are intermediate and very similar. Despite the difference in outcomes, the ranges of both the highest and lowest variant overlap slightly with the ranges of the intermediate variants. This reconfirms the conclusion that although the relative costs of the various closures are different, external uncertainties have a large effect on the absolute outcome of the analyses.

\section{Table 3.5}

Net effects of effort displacement on the net present value of the GVA (million euros) in the various scenarios and displacement scenarios

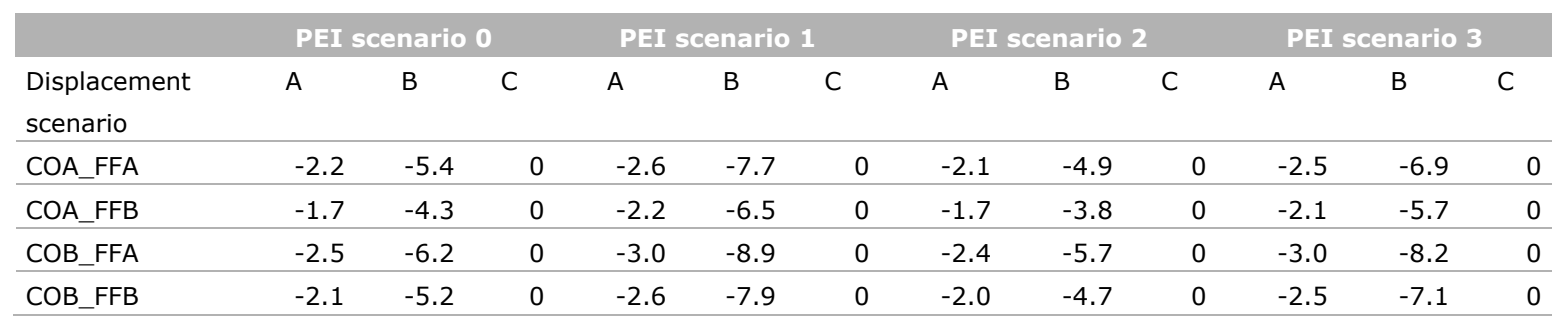

Source: Logbook data and VMS data, processed by LEI

\subsubsection{Sensitivity analysis}

In Van Oostenbrugge et al. (2015) an extensive sensitivity analysis is carried out on the effects of level of fishing activities in the areas, scenario parameters and the reference period (Section 6.2.3). As the effects are similar for most variants, that part of the report is also applicable to the results presented here. 


\section{Discussion and conclusions}

This note shows the potential costs of four variants of area closures in the Frisian Front and the Central Oyster grounds using the methodology developed for the cost-benefit analysis for area closures in the areas (Van Oostenbrugge et al., 2015). The costs for the Dutch fishing sector have been estimated using historic data on fishing activities in the variants and different PEI scenarios (Policy, Economics and Innovation scenarios) and displacement scenarios. The PEI scenarios have been developed to assess potential effects of external developments on the fishing activities in the areas. The displacement scenarios are used to estimate the costs in case the areas are closed. Each of the three displacement scenarios is based on a specific set of assumptions: Displacement scenario $A$ is based on scientific insights into the specific fishing opportunities in the areas (for non-quota species), the effects of crowding and the effect of fishermen's knowledge. Displacement scenario B is based on the view of fishermen's representatives and also includes costs for some vessels that will stop fishing. Displacement scenario $C$ assumes that the costs of the closures are negligible because fishermen will quickly adapt and find new fishing opportunities.

Depending on the assumptions taken, the costs range from 0 to $8.9 \mathrm{~m}$ euro. In general the costs of the two preferential variants (COA_FFA and COB_FFB) are very similar. The costs of variant COB_FFA are highest, approximately $20 \%$ higher than those of the preferential variants. The cost of variant COA_FFB are approximately $20 \%$ lower. The choice of the area in the Frisian Front is slightly more influential for the results than the choice of the area on the Central Oyster Grounds as the difference in total fishing activity between the subareas on the Frisian Front is somewhat higher.

When compared to the original variants as defined in Van Oostenbrugge et al. (2015), the effects on the fishing sector of the variants in this note are intermediate. The economic effect of variant COA_FFB, the least influential variant, is comparable to the effect of variant Capelin (Table 4.1). The effects of the other variants described here are intermediate between the effects of variant Capelin and variant Eel. The effects of the closures are relatively low, when taking into account that the total size of the closures is much larger $\left(2,400 \mathrm{~km}^{2}\right)$ than the surface area of variant Capelin $\left(1,600 \mathrm{~km}^{2}\right)$. The main reason for this is the fact that the extra $800 \mathrm{~km}^{2}$ is situated on the Central Oyster Grounds, which is fished much less intensively than the Frisian Front.

\section{Table 4.1}

Minimum and maximum net effects of effort displacement on the net present value of the GVA (million euros) in displacement scenarios $A$ and $B$ for the variants under study and the variants of Van Oostenbrugge et al. (2015). For displacement scenario $\boldsymbol{C}$ all costs are $\boldsymbol{O}$

\begin{tabular}{|c|c|c|c|c|}
\hline Displacement scenario & $A$ & & E & \\
\hline Variant & $\min$ & $\max$ & $\min$ & $\max$ \\
\hline Abalone & -1.4 & -1.6 & -3 & -4.6 \\
\hline Capelin & -1.8 & -2.2 & -3.9 & -6.1 \\
\hline Dab & -1.1 & -1.3 & -1.9 & -2.9 \\
\hline Flounder & -10.3 & -14.4 & -30.1 & -49.6 \\
\hline COA_FFA & -2.1 & -2.6 & -4.9 & -7.7 \\
\hline COA_FFB & -1.7 & -2.2 & -3.8 & -6.5 \\
\hline COB_FFA & -2.4 & -3.0 & -5.7 & -8.9 \\
\hline
\end{tabular}

Source: Logbook data and VMS data, processed by LEI 
Van Oostenbrugge et al. (2015) provides an extensive general discussion of the results. Here some highlights are summarised.

The estimation of the costs are based on numerous assumptions and various scenarios (both PEI scenarios and displacement scenarios). These scenarios are used to compare outcomes of the different variants and to test the robustness of the relative outcomes and ranking of the variants. Because of this, the outcomes are valid for the comparison of the four variants, but care should be taken when using the absolute numbers from the various scenarios in isolation (see also p. 117 of Van Oostenbrugge et al., 2015).

The costs of closures for the foreign fleets have not been taken into account in this addendum because of time constrains. However, Van Oostenbrugge et al. (2015) showed that the contribution of the foreign fishing activities in the Friesian Front and Central Oyster grounds to their GVA is approximately 1.2 to 2.0 times as high as for the Dutch fishing sector (Van Oostenbrugge et al., 2015, Table S.1). Based on this and assuming that the fishing patterns of the Dutch and foreign fleets are similar the contribution to the foreign fleets from the variants could be somewhere between 0.5 and $1.2 \mathrm{~m}$ euro per year. Because of the uncertainty in this estimate it is impossible to draw a conclusion on the relative contribution of individual variants to the GVA of foreign fleets.

Van Oostenbrugge et al. (2015) provides a full cost-benefit analysis of six variant closures including ecological benefits, social effects and costs for monitoring and enforcement. This note adds to this report by providing the economic effects of closures for the Dutch fishing sector and the results show that the choice for one variant or another will have different economic implications. However, in order to fully evaluate the benefits and costs for the variants under study it would be advisable to also take into account the other effects of the closures when evaluating the effectiveness of these measures in reaching the management objectives stated in the Dutch Marine Strategy Part 1 (Ministry of I\&M, Ministry of EZ, 2012). 


\section{References}

Bos, O.G., R. Witbaard, M. Lavaleye, G. van Moorsel, L.R. Teal, R. van Hal, T. van der Hammen, R. ter Hofstede, R. van Bemmelen, R.H. Witte, S. Geelhoed and E.M. Dijkman (2011): Biodiversity hotspots on the Dutch Continental Shelf: A Marine Strategy Framework Directive perspective, IMARES report C071/11 (http://edepot.wur.nl/174045).

Jongbloed, R.H., D.M.E. Slijkerman, R. Witbaard and M.M.S. Lavaleye (2013): Ontwikkeling zeebodemintegriteit op het Friese Front en de Centrale Oestergronden in relatie tot bodemberoerende visserij: Verslag expert workshop (http://edepot.wur.nl/288777). Report C212/13, IMARES.

Kuhlman, J.W. and J.A.E. van Oostenbrugge (2014): Bodemberoerende visserij op de Noordzee; Huidige situatie, recente ontwikkelingen en toekomstscenario's. Wageningen, LEI Wageningen UR (University \& Research Centre), LEI Report 2014-024.

Ministry of I\&M, Ministry of EZ (2012): Marine Strategy for the Netherlands part of the North Sea 2012-2020, Part 1

(http://www.noordzeeloket.nl/images/Marine\%20Strategy\%20for\%20the\%20Netherlands\%20par t\%20of\%20the\%20North\%20Sea\%202012-2020,\%20Part\%201_683.pdf), Ministry of Infrastructure and the Environment, Ministry of Economic Affairs.

Slijkerman, D.M.E., O.G. Bos, J.T. van der Wal, J.E. Tamis and P. de Vries (2013):

Zeebodemintegriteit en visserij op het Friese Front en de Centrale Oestergronden: Beschikbare kennis en eerste uitwerkingen (http://edepot.wur.nl/258211). Report C078/13, IMARES.

Slijkerman, D.M.E., J.T. van der Wal, R. Witbaard and M.S.S. Lavaleye (2014): Verkenning zoneringsmaatregelen met Marxan: Kaderrichtlijn Marien op het Friese Front en de Oestergronden (http://edepot.wur.nl/292232). Report C005/14, IMARES/NIOZ.

Taal, C., H. Bartelings, R. Beukers, A.J. Klok and W.J. Strietman (2010): Visserij in cijfers 2010. LEI-rapport 2010-057. ISBN 9789086153763. LEI, Den Haag 130 p.

Van Oostenbrugge, H., D. Slijkerman, K. Hamon, O. Bos, N. Hintzen, E. Bos, J.T. van der Wal and J. Coolen (2015): Effects of seabed protection on the Frisian Front and Central Oyster Grounds; A Cost Benefit Analysis. Wageningen, LEI Wageningen UR (University \& Research centre), LEI Report 2015-145. 
LEI Wageningen UR

P.O. Box 29703

2502 LS The Hague

The Netherlands

$\mathrm{T}+31(0) 703358330$

E publicatie.lei@wur.nl

www.wageningenUR.nl/en/lei

MEMORANDUM

LEI 2016-062
LEI Wageningen UR is one of the world's leading independent socio-economic research institutes. LEI's unique data, models and knowledge offer clients insight and integrated advice on policy and decision-making in an innovative manner, and ultimately contribute to a more sustainable world. LEI is part of Wageningen UR (University and Research centre), forming the Social Sciences Group together with the Department of Social Sciences and Wageningen UR Centre for Development Innovation.

The mission of Wageningen UR (University \& Research centre) is 'To explore the potential of nature to improve the quality of life'. Within Wageningen UR, nine specialised research institutes of the DLO Foundation have joined forces with Wageningen University to help answer the most important questions in the domain of healthy food and living environment. With approximately 30 locations, 6,000 members of staff and 9,000 students, Wageningen UR is one of the leading organisations in its domain worldwide. The integral approach to problems and the cooperation between the various disciplines are at the heart of the unique Wageningen Approach. 


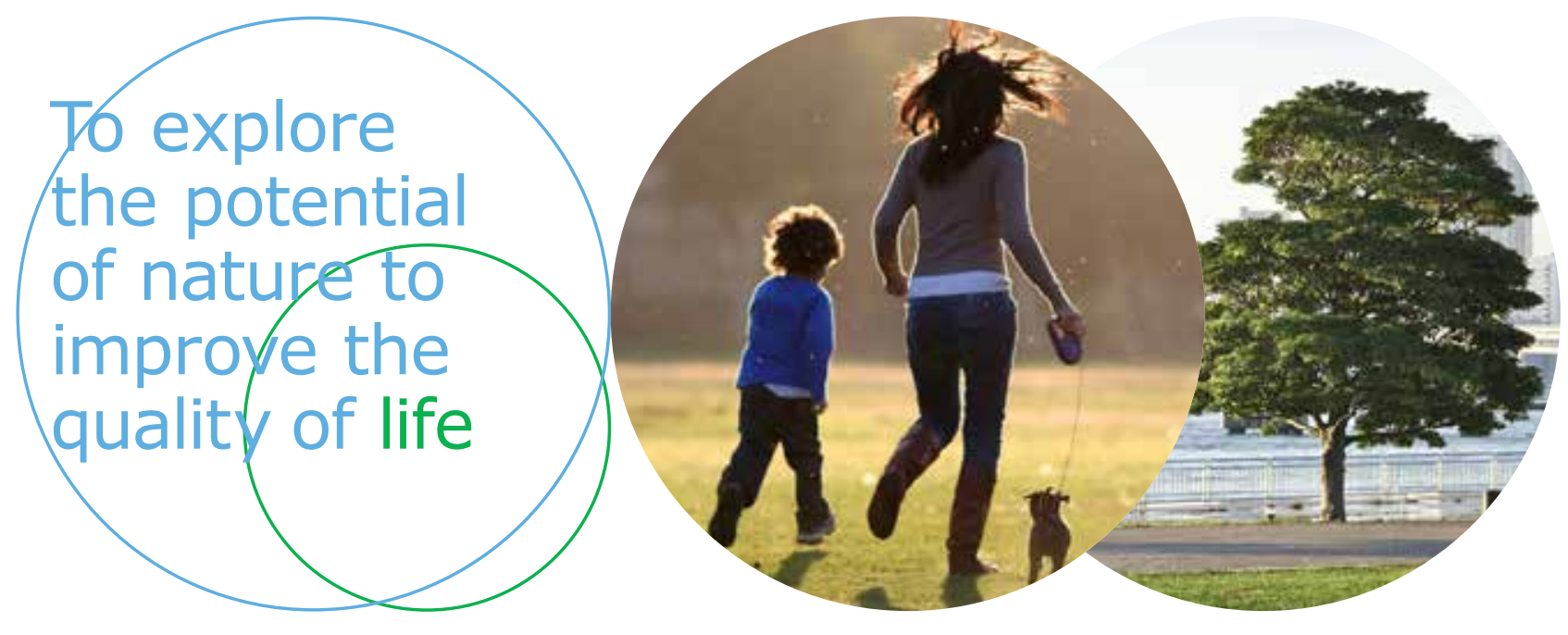

LEI Wageningen UR

P.O. Box 29703

2502 LS Den Haag

The Netherlands

E publicatie.lei@wur.nl

www.wageningenUR.nl/lei

MEMORANDUM

LEI 2016-062
LEI Wageningen UR is one of the world's leading independent socio-economic research institutes. LEI's unique data, models and knowledge offer clients insight and integrated advice on policy and decision-making in an innovative manner, and ultimately contribute to a more sustainable world. LEI is part of Wageningen UR (University and Research centre), forming the Social Sciences Group together with the Department of Social Sciences and Wageningen UR Centre for Development Innovation.

The mission of Wageningen UR (University \& Research centre) is 'To explore the potential of nature to improve the quality of life'. Within Wageningen UR, nine specialised research institutes of the DLO Foundation have joined forces with Wageningen University to help answer the most important questions in the domain of healthy food and living environment. With approximately 30 locations, 6,000 members of staff and 9,000 students, Wageningen UR is one of the leading organisations in its domain worldwide. The integral approach to problems and the cooperation between the various disciplines are at the heart of the unique Wageningen Approach. 